\title{
Integrating Environmental Justice into EPA Permitting Authority
}

\author{
Richard J. Lazarus* and Stephanie Tai*
}

CONTENTS

Introduction ......................................................... 618

I. Background: The Meaning of "Environmental Justice" in the EPA Permitting Context ...............................620

A. Community Participation ...............................621

B. Risk Aggregation........................................622

C. Risk Disproportionality .................................623

II. Survey of Federal Statutory Provisions Authorizing Permit Conditions or Denials Based on Environmental Justice

A. Title VI of the Civil Rights Act of 1964 and EPA's Interim Guidance for Investigating Title VI Administrative Complaints Challenging Permits 627

B. Clean Air Act 631

C. Clean Water Act............................................6 639

D. Resource Conservation and Recovery Act..............642

E. Safe Drinking Water Act ................................647

F. Toxic Substances Control Act ............................648

G. Federal Insecticide, Fungicide, and Rodenticide Act 649

Copyright $\odot 1999$ by ECOLOGY LAW GUARTERLY

- John Carroll Research Professor of Law, Georgetown University Law Center. Member, NEJAC (1994-1997); Member, USEPA's National Advisory Council for Environmental Policy and Technology. Title VI Implementation Advisory Committee (1998-1999). An earlier version of this Article was produced as a subcommittee report in 1995 by one of the authors in his capacity as a member of EPA's National Advisory Council on Environmental Justice (NEJAC). NEJAC, in turn, reviewed the report and adopted several formal resolutions consistent with the report's recommendations. An early draft was also presented at the 1999 Air and Waste Management Association Environmental Permitting Symposium, held this past February in Research Triangle Park, North Carolina. Thanks are owed to Mary O'Lone of the United States Environmental Protection Agency Office of General Counsel who performed some of the earliest research on related issues.

** J.D. candidate, Georgetown University Law Center, 2000; Ph.D., Chemistry, Tufts University, 1997. 
III. Environmental Permitting Guidelines Incorporating Environmental Justice Concerns: Experiences from EPA Regional Offices.........................................6650

A. Experiences from EPA Region V ......................651

1. Resource Conservation and Recovery Permitting 651

2. Lead Permitting .........................................652

3. Air and Radiation Division Environmental Justice Implementation Plan .........................653

B. Experiences from Region IX Air Division

Environmental Justice Strategy 654

IV. EPA Environmental Appeals Board Decisions

Regarding the Relationship of Environmental Justice to EPA Permitting Authority ..................................655

A. Lack of Environmental Justice Authority ..............657

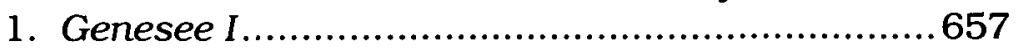

2. Genesee II ............................................658

3. Lessons Learned from the Genesee Decisions.....659

B. Increasing Willingness to Find Discretionary Authority .................................................66 660

1. In re Chemical Waste Management, Inc. .............660

2. In re Puerto Rico Electric Power Authority ...........664

3. In re Envotech, L.P...................................665

C. Recognition of Authority ...............................668

1. In re EcoElectrica, L.P. .............................669

2. In re Ash Grove Cement Co. .........................670

3. In re Environmental Disposal Systems, Inc. .........673

4. In re Knauf Fiber Glass, GmbH .......................6674

5. In re AES Puerto Rico, L.P.............................675

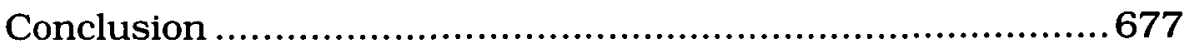

\section{INTRODUCTION}

Although much of the environmental justice movement and related environmental law scholarship to date have focused on the need to apply civil rights law to decisions made by government officials pursuant to environmental laws, ${ }^{1}$ environmental justice advocates have long recognized that the best protection may prove to be within the environmental laws

1. See, e.g., Edward Patrick Boyle, Note, It's Not Easy Being Green: The Psychology of Racism, Environmental Discrimination, and the Argument for Modemizing Equal Protection Analysis, 46 VAND. L. REv. 937 (1993); James H. Colopy, Note, The Road Less Traveled: Pursuing Environmental Justice Through Title VI of the Civil Rights Act of 1964, 13 STAN. ENVTL. L.J. 125 (1994); Rachel D. Godsil, Note, Remedying Environmental Racism, 90 MicH. L. REV. 394 (1991). 
themselves. ${ }^{2}$ Environmental law's ability to provide such redress, however, turns largely on the answers to controversial questions respecting permitting decisions under existing federal environmental statutes. The first question is whether the Environmental Protection Agency (EPA) has the authority to condition on environmental justice grounds permits that the Agency (and states with federally-approved programs) issues to regulated entities pursuant to the various federal environmental protection laws administered by EPA. The second related question is the extent to which that permitting authority (federal or state) may deny a permit altogether solely on environmental justice grounds. ${ }^{3}$

This Article addresses the extent of EPA's environmental justice conditioning authority, first, by examining federal environmental statutory provisions that may authorize such permitting conditions; then, by surveying the ways that various EPA regional offices have incorporated such concerns into their permitting guidelines; and finally, by reviewing Environmental Appeals Board decisions regarding the relationship between environmental justice concerns and EPA permitting authority. This Article does not address the distinct question of whether EPA is required under existing statutory provisions to impose such conditions or deny such permits. Plainly, EPA's statutory authority is broader than its statutory obligations. The question posed is to what extent EPA may choose to exercise such authority in the permitting process to promote environmental justice concerns. Of course, if one concludes that such discretionary authority does exist, circumstances will inevitably arise in which the failure to exercise such discretion would amount to an abuse of discretion.

This Article is divided into four Parts. First, the Article describes in general terms the kinds of environmental justice concerns that might be implicated in the permitting context and the types of conditions that might be imposed in response to those concerns. Second, the Article surveys various federal

2. See Michael B. Gerrard, The Role of Existing Environmental Laws in the Environmental Justice Movement, 9 ST. JOHN'S J. LEGAL COMMENT. 555 (1994); see also Alice Kaswan, Environmental Justice: Bridging the Gap Between Environmental Laws and "Justice", 47 AM. U. L. REV. 221 (1997).

3. See, e.g., In re Louisiana Energy Services, L.P., 47 N.R.C. 77 (1998) (finding that the National Environmental Policy Act, 42 U.S.C. \$\$ 4321-4370e (1994), required the Nuclear Regulatory Commission to consider environmental justice impacts in the Commission's licensing process and remanding a nuclear material license for agency review to determine whether such concerns were adequately considered). 
environmental laws for statutory and regulatory language that might provide a legal basis for EPA to condition permits or to deny them altogether on environmental justice grounds. Included in this discussion is an analysis of the effect that EPA's Interim Guidance for Investigating Title VI Administrative Complaints Challenging Permits ${ }^{4}$ may have on permitting obligations and discretionary authority, as well as brief analyses of certain provisions within each of the laws that readily lend themselves to the injection of environmental justice concerns. Third, the Article examines ways in which these concerns described in the first Part have already been incorporated by some EPA regional offices as part of an overall effort to comply with the President's executive order on environmental justice. Finally, the Article discusses several EPA permitting decisions addressing the relevance of environmental justice concerns to EPA's permitting authority.

I

BACKGROUND: THE MEANING OF "ENVIRONMENTAL JUSTICE" IN THE EPA PERMITTING CONTEXT

In the context of an EPA permitting decision, the core expression of environmental justice is that EPA should take into account the racial and/or socioeconomic makeup of the community most likely to be affected adversely by the environmental risks of a proposed activity. ${ }^{5}$ This involves two steps: the identification of the environmental justice community and the incorporation of that community's concerns into the permitting process. $^{6}$ Taking into account the makeup of the community does not mean that EPA must automatically deny a permit solely because the affected area is a community of color or low-income. ${ }^{7}$ The Agency's inquiry into these characteristics of the community is, however, necessary to allow the Agency to

4. U.S. ENVTL. PRotection AgenCY, INTERIM GuidanCe For INVEstigating Title VI AdMinistrative Complaints CHALlenging PERmits (1998) (on file with author) [hereinafter INTERIM GUIDANCE].

5. See Gerald Torres, Changing the Way Government Views Environmental Justice, 9 ST. JOHN'S J. LEGAL COMMENT. 543, 547-51 (1994).

6. See Conference, U.S. Environmental Protection Agency Office of Environmental Justice in the Matter of the Fifth Meeting of the National Environmental Justice Advisory Council, 9 ADMIN. L.J. AM. U. 623, 768 (1995) (describing Region V's efforts to proactively identify "environmental justice areas of concern" and to incorporate environmental justice considerations into "work practice").

7. See Michael Fisher, Environmental Claims Brought Under Title VI of the Civil Rights Act, 25 ENVTL. L. 285, 319-21 (1995) (concluding that environmental justice activists need to demonstrate that a project results in disparate impact in order to successfully pursue an environmental justice claim under Title VI case law). 
make an informed permitting decision regarding the actual environmental and health effects of a permit applicant's proposed activity.

The permitting agency might, for example, issue a permit on the condition that the permittee arrange to undertake a series of measures designed to redress environmental justice concerns. Some of the environmental justice concerns that can be addressed through permit conditions are discussed below. They include the enhancement of a community's capacity to participate in environmental enforcement and compliance assurance, assessment of risk aggregation or cumulative risk, and identification of disproportionality in risk imposition. The relevance of each of these concerns to the permitting process is fairly clear. What is less clear to those officials responsible for issuing the permits is whether they have the necessary authority to consider such concerns and to take actions, including the imposition of permit conditions, based upon those concerns. ${ }^{8}$

\section{A. Community Participation}

Community enforcement and compliance assurance play key roles in relating environmental justice concerns to permitting decisions. ${ }^{9}$ Congress deliberately included citizen suit enforcement provisions in federal environmental protection laws because of its awareness that government enforcement resources would necessarily be insufficient (and unreliable) to establish the credible enforcement threat needed to promote compliance. ${ }^{10}$ One of the central teachings of environmental justice, however, is that environmental justice communities have historically lacked the resources needed to monitor polluting facilities in their

8. See Eileen Gauna, Major Sources of Criteria Pollutants in Nonattainment Areas: Balancing the Considerations of Clean Air, Environmental Justice, and Industrial Development, 3 HASTINGS W.-N.W. J. ENVTL. L. \& POL'Y 379, 394 (1996) (finding it "unclear to what extent the permitting authority can and will consider the environmental justice implications of a PSD permit").

9. See OFFICE OF THE AdMINISTRATOR, U.S. ENVTL. PROTECTION AGENCY, THE NEW GENERATION OF ENVIRONMENTAL PROTECTION: A SUMMARY OF EPA'S FIVE-YEAR STRATEGIC PLAN 6-7 (1994) (emphasizing importance of compliance monitoring, inspections, and enforcement actions, as well as involvement of all stakeholders).

10. See 116 CONG. REC. 32,927 (1970) (statement of Sen. Muskje during debate on Clean Air Act citizen suit provisions) ("I think it is too much to presume that, however well staffed or well intentioned these enforcement agencies, they will be able to monitor the potential violations."); see also Jeannette L. Austin, Comment. The Rise of Citizen-Suit Enforcement in Environmental Law: Reconcling Private and Public Attorneys General, 81 Nw. U. L. REV. 220 (1987) (discussing the role of citizen suits in federal environmental enforcement). 
neighborhoods for possible violations ${ }^{11}$ and, if found, to negotiate their correction, to persuade federal or state enforcement officials to take action, or to bring citizen suit enforcement actions against violating facilities. ${ }^{12}$

For this reason, the permitting process could promote environmental justice if permitting authorities possessed the authority to impose upon permittees conditions providing affected communities with greater capacity to oversee and ensure permit compliance. An effective permit condition might seek to redress the resource deficiencies of environmental justice communities by making monitoring reports more readily available to the community. ${ }^{13}$ Or such conditions could reach further by giving the community access to the facility for inspection, funding a community oversight operation, or providing legal assistance to the community. ${ }^{14}$

\section{B. Risk Aggregation}

A dimension of environmental justice relevant to the permitting process concerns the extent to which the permitting authority can incorporate the cumulative environmental risks facing a community in its permitting decisions. EPA is well aware that risk aggregation may occur in environmental justice communities. ${ }^{15}$ The challenge is to consider the extent to which

11. See Eileen Gauna, Federal Environmental Citizen Provisions: Obstacles and Incentives on the Road to Environmental Justice, 22 ECOLOGY L.G. 1, 31-32 (1995); see also Robert W. Collin, Environmental Equity: A Law and Planning Approach to Environmental Racism, 11 VA. ENVTL. L.J. 495, 511-13 (1992): Colin Crawford, Strategies for Environmental Justice: Rethinking CERCLA Medical Monitoring Lawsuits, 74 B.U. L. REV. 267, 268-70 (1994).

12. See Richard J. Lazarus, The Meaning and Promotion of Environmental Justice. 5 MD. J. CONTEMP. LEGAL ISSUES 1, 4-6 (1994) (describing how lack of resources in the face of environmental law's sheer complexity makes it difficult to take advantage of citizen suit provisions).

13. See COMMISSION FOR RACIAL JUSTICE, UNITED CHURCH OF CHRIST, TOXIC WASTES AND RACE IN THE UNITED STATES, A NATIONAL REPORT ON RACIAL AND SOCIO-ECONOMIC CHARACTERISTICS OF COMMUNITIES WITH HAZARDOUS WASTE SITES 24 (1987) (recommending that EPA monitor siting of facilities to ensure environmental justice characteristics are considered).

14. Various environmental justice advocacy centers may serve as models for such efforts. These centers provide services such as leadership training, technical assistance, and education to impacted communities. See generally Carita Shanklin, Pathfinder: Environmental Justice, 24 ECOLOGY L.Q. 333, 352-56 (1997).

15. The Executive Order on Federal Action to Address Environmental Justice in Minority and Low-Income Populations Section 3-301(b) states that "Environmental human health analyses, whenever practicable and appropriate, shall identify multiple and cumulative exposures." Exec. Order No. 12,898, 3 C.F.R. 859 (1995), reprinted in 42 U.S.C. \$ 4321 (1994) [hereinafter Executive Order]; see also Robert R. Kuehn, The Environmental Justice Implications of Guantitative Risk Assessment, $1996 \mathrm{U}$. ILL. 
existing statutory and regulatory authorities permit EPA (or a state or local permitting agency) to address the problem.

For example, it would seem sensible that when a permitting agency knows or has reason to believe that a particular community is exposed to cumulative environmental and health risks from a variety of existing sources, that agency should be able to take such risks into account when deciding whether, or to what extent, to allow additional risks from a newly proposed activity. Although the bottom line for the permitting agency in those circumstances remains environmental and health risks, knowledge of the community's character may be necessary for the permitting agency to apprehend fully the nature of these risks to consider these risks in aggregation. ${ }^{16}$ Risks that seem acceptable in isolation may be more properly seen as unacceptably high when the broader social context, including associated health and environmental risks, is accounted for in total aggregation. ${ }^{17}$

As with community participation, cumulative effects could in theory be addressed through the permitting process in a variety of ways. In extreme circumstances, the permitting authority might have to deny the permit altogether. In other cases, the risks authorized by the permit might need to be reduced in light of the risks the community already faces. Finally, the permitting authority might create a host of permit conditions designed to guard against unacceptably high cumulative risk, including conducting studies and possibly imposing further permit restrictions based upon the results of such studies.

\section{Risk Disproportionality}

A third distinct inquiry relates to the Agency's authority to consider disproportionality or equity concerns. This third aspect of environmental justice is related to the unacceptably high aggregation (or cumulative impact) issue, as aggregation is the fundamental cause of disproportionality. Furthermore, in many circumstances aggregation and disproportionality occur simultaneously; in such instances, accounting for aggregation may make it possible for the Agency to realize that one

L. REV. 103, 151-52 (1996).

16. See Gauna, supra note 8, at 404 (arguing that permitting authorities should "use existing data bases to determine the likelihood of the host community's disparate exposure to environmental risks").

17. See Kuehn, supra note 15, at 152 (discussing the need to evaluate particular risks in light of existing risks within the context of EPA's risk assessment guidelines). 
community is exposed to unacceptably high levels of risk while another community is not. ${ }^{18}$

But for many, equity is a legitimate consideration, independent of whether aggregation of risk violates EPA's established environmental or human health norms for acceptable risk. ${ }^{19}$ They would like to see EPA deny or condition a permit based on whether the affected community would otherwise be subject to a disproportionate share of environmental risk. ${ }^{20}$ Thus, proof of disproportionality alone would be sufficient. There would be no additional need to establish that the level of risk was otherwise unacceptably high from either a health or environmental perspective. In short, disproportionality itself would be presumptively unreasonable or perhaps even per se unreasonable, absent mitigating permit conditions.

These three examples of environmental justice considerations relevant to permitting-promoting community enforcement capacity, accounting for risk aggregation, and redressing risk disproportionality - are illustrative. No doubt there are many other environmental justice considerations that could be factored into Agency permitting decisions. This list, however, need not be exhaustive. Instead, this Article addresses the threshold issue of the relevance of environmental justice to EPA's exercise of its permitting authority under the various environmental laws. These three examples offer a basis for addressing that threshold issue. The extent of this authorityhow much permitting agencies may deny or condition permits on such grounds- will determine the reach of environmental justice in the permitting context.

18. See Sheila Foster, Justice from the Ground Up: Distributive Inequities, Grassroots Resistance, and the Transformative Politics of the Environmental Justice Movement, 86 CAL. L. REV. 775, 782 (1998) (examining EPA's use of its own studies which found that residents of Chester, Pennsylvania, had unacceptably high blood lead levels).

19. See id. (discussing how environmental justice is about procedural equity as well as distributional equity); see also ROBERT V. PERCIVAL ET AL., ENVIRONMENTAL REgulation: LAW, SCIENCE, AND POLICY 188 (2nd ed. 1996) ("[I]t is necessary to consider not only how efficient [environmental] policies are, but also how equitable."); Cheryl A. Calloway \& Karen L. Ferguson, The "Human Environment" Requirement of the National Environmental Policy Act: Implications for Environmental Justice, 1997 DET. C.L. REV. 1147, 1151 (1997).

20. See Gauna, supra note 8 , at 394 (advocating that the showing of disproportionate exposure and availability of an alternative site should be valid grounds for permit denial). 
II

SURVEY OF FEDERAL STATUTORY PROVISIONS AUTHORIZING PERMIT CONDITIONS OR DENIALS BASED ON ENVIRONMENTAL JUSTICE

The history of environmental law is replete with instances when broadly worded statutory language or regulations have been successfully enlisted in support of arguments that the federal government has authority or obligations beyond those initially contemplated by the regulated entities, environmentalists, affected communities, or even the government itself. The Refuse Act's restrictions on water pollution, ${ }^{21}$ the National Environmental Policy Act's strict procedural requirements, ${ }^{22}$ the Clean Air Act's program for the prevention of significant deterioration, ${ }^{23}$ and the Clean Water Act's Section $401^{24}$ are all very much products of such innovative and expansive interpretations of existing statutory language.

The issue here is the extent to which existing statutory and regulatory language can similarly be resurrected on behalf of environmental justice. By examining the statutory language of several environmental protection laws, this Part of the Article identifies other clauses that might support expansive interpretations of EPA's authority to promote environmental justice through permit conditions and denials. The Environmental Appeals Board opinions discussed later have set forth some possibilities: the omnibus clause contained in the Resource Conservation and Recovery Act's Section 3005(c)(3), ${ }^{25}$ discussed in In re Chemical Waste Management, Inc. ${ }^{26}$ and the

21. 33 U.S.C. § 407 (1994); see United States v. Standard Oil Co., 384 U.S. 224 (1966) (holding that the Refuse Act, which addressed navigable waters, covered discharges of industrial wastes regardless of whether the wastes threatened navigation).

22. 42 U.S.C. \& 4332 (1994); see Calvert Cliffs Coordinating Comm. v. United States Atomic Energy Comm'n, 449 F.2d 1109 (D.C. Cir. 1971) (finding that because the National Environmental Policy Act mandates informed decisionmaking, an agency's environmental impact statement was invalid when the agency was found not to have given that statement consideration).

23. 42 U.S.C. $\$ \S 7470-7515$ (1994); see Sierra Club v. Ruckelshaus, 344 F. Supp. 253 (D.D.C. 1972) (holding that EPA could not approve state implementation plans if those plans did not include provisions to prevent significant deterioration, even if those implementation plans met the national ambient air quality standards), aff'd by an equally divided court sub nom. Fri v. Sierra Club, 412 U.S. 541 (1973).

24. 33 U.S.C. $\$ 1341$ (a)(1) (1994); see Public Util. Dist. No. 1 v. Washington Dep't of Ecology, 511 U.S. 700 (1994) (holding that a state may impose a minimum stream flow rate condition on a dam certification permit).

25. 42 U.S.C. \$ 6925(c)(3) (1994) ("Each permit issued under this section shall contain such terms and conditions as the Administrator (or the State) determines necessary to protect human health and the environment.").

26. 1995 WL 395962 (E.P.A. June 29, 1995). 
omnibus clause contained in the Safe Drinking Water Act regulations, 40 C.F.R. $\$ 144.52(a)(9)$, discussed in In re Envotech, L.P. ${ }^{27}$

This review does not purport to exhaust all of the statutory possibilities and is deliberately speculative in nature. For example, this Article exclusively addresses existing federal statutory and regulatory language. It does not inquire into the relevant laws of each of the fifty states or their respective local governments, even though many of the relevant permitting decisions are made by those state and local authorities pursuant to their own environmental statutes and regulations.

The reason for this Article's limited inquiry is practical. But because so much of state and local environmental permitting law finds its origins, and indeed impetus, in the overarching minimum federal environmental requirements, this Article's discussion of federal requirements is relevant to state and local permitting authorities as well. In any event, this Article does not aim to answer all the legal issues raised by environmental justice and permitting. Instead, it seeks to prompt others, especially federal, state, and local government officials far more familiar with the statutory and regulatory intricacies of the various programs, to take the initiative to determine the full reach of the provisions briefly outlined in this Article and, even more importantly, to discover other authorities as well. ${ }^{28}$

27. 1996 WL 66307 , at $* 13$ (E.P.A. Feb. 15, 1996); 40 C.F.R. \& 144.52(a)(9) (1998) ("The Director shall impose on a case by case basis such additional conditions as are necessary to prevent the migration of fluids into underground sources of drinking water.").

28. Very recent events also suggest that at least EPA may now be ready to undertake more ambitious steps to exercise its statutory authority in the permitting area to address environmental justice concerns. Just as this Article was going to press, EPA announced that it would be conducting a three-day meeting of EPA's National Environmental Justice Advisory Council, from November 30 to December 2, 1999, to discuss the issues raised and discussed in this Article. In addition to an overview of some of the statutory authorities described herein, other topics for panel discussions by representatives from EPA, state environmental agencies, tribal representatives, local government, industry, and environmental community organizations include: (1) Addressing the Real Life Dilemmas of Environmental Justice in Permitting: How Do We Respond to the Legacy of Land Use Impacts?; (2) The Current State of Environmental Justice and Permitting: What Are Its Limitations?; and (3) Opportunities for Improvement: What Factors Should EPA Consider to Help Ensure Environmental Justice in Permitting? The source of this information is a conversation one of the authors had with Mr. Charles Lee, Director of Policy, U.S. EPA Office of Environmental Justice, on October 7, 1999. 
A. Title VI of the Civil Rights Act of 1964 and EPA's Interim Guidance for Investigating Title VI Administrative Complaints Challenging Permits

In addition to a Presidential executive order on environmental justice, ${ }^{29}$ the EPA's regulations implementing Title VI of the Civil Rights Act of $1964^{30}$ suggest the need for, if not the obligation of, environmental permitting agencies to utilize the full extent of their existing authority to consider and promote environmental justice in their permitting decisions. President Clinton signed Executive Order No. 12,898 on "Federal Actions to Address Environmental Justice in Minority and Low Income Populations" on February 11, 1994. ${ }^{31}$ That executive order requires all federal agencies, including EPA, to consider and address environmental justice concerns in exercising their statutory authorities.

In an accompanying memorandum, federal agencies were further directed to ensure that the programs they funded complied with the nondiscrimination requirements of Title VI. ${ }^{32}$ Although Title VI addresses intentional discrimination, it authorizes EPA to adopt implementing regulations that prohibit discriminatory effects as well as intent. ${ }^{33}$ All recipients of EPA funding must comply with EPA's Title VI regulations, including "any State or its political subdivision, any instrumentality of a State or its political subdivision ... to which Federal financial assistance is extended directly or through another recipient," ${ }^{34}$ unless expressly exempt by federal statute.

EPA's Title VI regulations, like those of other federal agencies, bar funding activities with discriminatory effect as well as discriminatory intent. Only recently, however, has EPA developed formal guidance for implementing its Title VI regulations. Because this guidance concerns Title VI challenges in particular, and not environmental justice in general, the guidance does not explicitly include socioeconomic makeup in any of its analyses.

EPA's Interim Guidance for Investigating Title VI Administrative Complaints Challenging Permits (Interim Guidance), issued on February 2, 1998, addresses the processing

29. See Executive Order, supra note 15.

30. 42 U.S.C. $\$ \$ 2000 d$ to $2000 d-7$ (1994).

31. Executive Order, supra note 15.

32. See 42 U.S.C. $\$ \$ 2000 d$ to $2000 d-7$ (1994).

33. See 40 C.F.R. \$\$ 7.10-7.135 (1998).

34. Id. § 7.25. 
of racially discriminatory effects allegations with respect to federally funded permitting programs. ${ }^{35}$ The Interim Guidance does not advise whether the federally funded permitting agencies themselves possess their own independent authority to regulate according to environmental justice principles. Furthermore, the Interim Guidance states that it does not alter the substantive authority already possessed by those agencies. Instead, the Interim Guidance states that EPA's Office of Civil Rights (OCR) will consider discriminatory impacts regardless of whether the permitting agencies are themselves independently authorized to guard against such impacts because "Title VI is a Federal crosscutting statute that imposes independent, nondiscrimination requirements on recipients of Federal funds. ${ }^{\text {36 }}$ In order to receive federal funds, agencies must comply with the Title VI requirements addressed in the Interim Guidance. Its effect, therefore, is to force federally funded state and local permitting agencies to extend the application of their authority to providing and conditioning permits on environmental justice grounds.

The Interim Guidance initially provides a gatekeeping inquiry in which EPA's OCR factually determines whether a challenged permit will create disparate impacts unless the complaints are "so insubstantial or incoherent that they cannot be considered to be grounded in fact. ${ }^{n 7}$ If disparate impacts on a racial or ethnic population are found, then the permitting agency can rebut the finding of disparate impacts or demonstrate a substantial, legitimate interest "justify[ing]" the decision to proceed notwithstanding the disparate impacts. ${ }^{38}$ "Justification," in the Interim Guidance, includes considering mitigating alternatives. ${ }^{39}$ If a permitting agency can neither rebut nor justify the impacts at issue, OCR will send the agency a notice of noncompliance. ${ }^{40}$

The Interim Guidance emphasizes primarily aggregate effects. Although it allows for exceptions in cases of "unique" permitted activities, the Interim Guidance states: "[o]rdinarily, OCR will entertain cases only in which the permitted facility at issue is one of several facilities, which together present a cumulative

35. See InTERIM GUIDANCE, supra note 4; see also Bradford C. Mank, Environmental Justice and Title VI: Making Recipient Agencies Justify the Siting Decisions, 73 TULANE L. REV. 787 (1999).

36. INTERIM GUIDANCE, supra note 4, at 9 n. 12 .

37. Id. at 6.

38. Id. at 12 .

39. Id.

40. See id. at 5 (specifying that such notice will be sent within 180 calendar days from the start of the complaint investigation). This notice may include the OCR's recommendations for the means to achieve voluntary compliance. See id. 
burden or which reflect a pattern of disparate impact. ${ }^{\text {"41 }}$ Furthermore, it explicitly goes beyond the public health norms and environmental protection baselines in EPA's other programs and recognizes that discriminatory effects may occur "where residual pollution and other cognizable impacts are distributed disproportionately." ${ }^{22}$ This consideration of disproportionality is partly incorporated into the analysis of cumulative burdens, as the Interim Guidance finds that disproportional effects are more likely "where an individual permit contributes to or compounds a preexisting burden being shouldered by a neighboring community." 43 However, a finding of disparate impact is enough to shift the burden of proof to the permitting agency to demonstrate either mitigation or justification.

The Interim Guidance recognizes that some of a facility's disparate impacts on surrounding communities can be addressed through mitigation programs, presumably including the imposition of permit conditions. The Interim Guidance also advises the OCR to evaluate the sufficiency of these programs in consultation with EPA experts as well as with complainants. The Interim Guidance further recognizes that disparate impacts can be mitigated through supplemental mitigation projects, which can include concerns "associated with the permitting of the

41. INTERIM GUIDANCE, supra note 4 , at 10.

42. Id. at 11. There is embedded within the concept of "cognizable impact" a critical threshold issue affecting the ultimate scope of Title VI's nondiscrimination mandate. Environmental justice advocates generally assert that the scope of relevant impacts for Title VI purposes extends to any impact of the facility being permitted. Hence, any discriminatory impacts that would be caused by the operating facility, ranging not only from human health and environmental effects, but extending to economic, social, and cultural effects, could be the potential basis of a Title VI discrimination claim. Not surprisingly, those in the regulated community (and most state regulators) favor a more restrictive view of what constitutes a "cognizable impact" under Title VI. Under the more restrictive approach, an impact would be cognizable if it were an actual impact on human health (or perhaps a substantial, credible risk thereof). EPA has not yet reached a final decision on this critical threshold issue. Because, however, it seems likely that the Agency will ultimately decide that the scope of cognizable impacts under Title VI is confined to those considerations that are relevant under the permitting agency's statutory grant of authority in deciding to grant (or not to grant or condition) the permit at issue, whether a permitting agency possesses the statutory authority to address environmental justice concerns takes on even more significance. If the relevant permitting provision allows the agency to consider risks of human health effects, not just actual human health effects, and socioeconomic factors, then those same risks and factors can theoretically form the basis of a discrimination claim even under a narrower Agency reading of what constitutes a "cognizable impact" under Title VI. See genenally U.S. ENVTL. PROTECTION AGENCY, REPORT OF THE TTTLE VI IMPLEMENTATION ADVISORY COMMTTEE: NEXT STEPS FOR EPA, STATE, AND LOCAL ENVIRONMENTAL JUSTICE PROGRAMS 57-65 (1999).

43. INTERIM GUIDANCE, supra note 4 , at 11 . 
facility" but "outside those considerations ordinarily entertained by the permitting authority." 44 Such language may encourage agencies to use their authority to the fullest extent to address environmental justice concerns in the permitting process. ${ }^{45}$

If the disparate impacts cannot be sufficiently mitigated, agencies also have the opportunity to justify their permit issuance. However, the Interim Guidance cautions that "merely demonstrating that the permit complies with applicable environmental regulations will not ordinarily be considered a substantial, legitimate justification." ${ }^{46}$ Instead, articulable factors should be considered in evaluating any particular justification: factors such as the demonstrability of benefits, whether or not the environmental community will reap the benefits of a facility, the seriousness of disparate impacts, and broader governmental interests.

Community participation is not addressed as strongly in the Interim Guidance as the conditioning of permits on environmental justice grounds. ${ }^{47}$ The Interim Guidance does not mandate providing potential complainants with the analytical support historically lacking in environmental justice communities, ${ }^{48}$ although once a complaint is filed, OCR uses its resources to investigate and evaluate the complaint. Furthermore, the Interim Guidance addresses only permit

44. Id. at 12 (emphasis added). The possibility of mitigation through supplemental mitigation projects raises a host of issues. At the outset, there is the threshold issue of whether any mitigation, short of either elimination of the disparate impact or a "justification" for the impact, can ever legitimately offset what would otherwise constitute an unlawful discriminatory impact. Assuming, however, that mitigation can play a valid, independent role, its applicability will turn greatly on the extent to which the proposed mitigation must address the effects giving rise to the disparate impact. There are two dimensions to this "nexus" inquiry. One relates to the extent to which the mitigation must address the same effects or at least, the same kind of effects. The other concerns the degree to which the mitigation must provide offsetting benefits. With respect to the latter, there is a further temporal inquiry related to the possibility that impacts could be tolerated today in exchange for the promise of benefits in the future (or vice versa). See generally REPORT OF THE TITLE VI IMPLEMENTATION ADVISORY COMMITTEE, supra note 42, at 82-90.

45. See, e.g., INTERIM GUIDANCE, supra note 4 , at 5 (recommending means for voluntary compliance); id. at 11-12 (encouraging adoption of mitigation to respond to concerns "outside those considerations ordinarily entertained by the permitting authority"); id. at 12 (rejecting "justification" if a less discriminating alternative is shown).

46. Id. at 12 .

47. See id. at 6 (encouraging participation in informal resolution with complainant).

48. See Lazarus, supra note 12, at 4-6; see also Gauna, supra note 11 , at 9. Such support may help complainants with little legal background understand how potential claims might fit into the existing network of environmental law. 
challenges filed after permits have been issued, when it is too late for an environmental justice community to participate in the actual permitting process. The single avenue provided by the Interim Guidance for participation and oversight during the permitting process is the referral to the permitting agency of complaints filed prior to permit issuance. ${ }^{49}$ However, because such complaints are kept on file, the complaint is available to the OCR if it investigates the suspected discriminatory impact of a permit once it is issued.

\section{B. Clean Air Act}

The Clean Air Act $(\mathrm{CAA})^{50}$ presents EPA with more opportunities to integrate environmental justice concerns into the Act's substantive standards than the Agency has utilized. The national ambient air quality standards (NAAQS) that serve as the Act's cornerstone are illustrative. Pursuant to the CAA, EPA administrators must promulgate NAAQS to protect "public health" with an adequate margin of safety. ${ }^{51}$ It is well settled that Congress intended for EPA to consider especially sensitive subpopulations in determining what pollutant levels would meet the "public health" standard. ${ }^{52}$ Pollutant levels that pose no health hazard to average healthy individuals may nonetheless present significant hazards to some individuals who, because of preexisting physical conditions, have heightened vulnerabilities. ${ }^{53}$ The Act, accordingly, instructs EPA in developing the "air quality criteria" upon which the NAAQS are based to include information on "those variable factors . . . which of themselves or in combination with other factors may alter the effects on public health or welfare. ${ }^{54}$

Because members of environmental justice communities

49. INTERIM GUIDANCE, supra note 4 , at 8 .

50. 42 U.S.C. \$\$ 7401-7671q (1994).

51. Id. $\S 7409(\mathrm{~b})(1)$.

52. See, e.g. American Lung Ass'n v. EPA, 134 F.3d 388, 389 (D.C. Cir. 1998) (quoting S. REP. No. 91-1196, at 10 (1970)) ("Congress defined public health broadly. NAAQS must protect not only average healthy individuals, but also 'sensitive citizens-children, for example, or people with asthma, emphysema, or other conditions rendering them particularly vulnerable to air pollution."); Lead Indus. Ass'n v. EPA, 647 F.2d 1130, 1152 (D.C. Cir. 1980) ("TThe [Senatel report is particularly careful to note that especially sensitive persons such as asthmatics and emphysematics are included within the group that must be protected.").

53. For example, EPA promulgated a lower NAAQS for lead because of the special sensitivities faced by some individuals, such as preschool-age children and pregnant women. See Lead Indus., 647 F.2d at 1141 (noting risks to preschool-age children and pregnant women).

54. 42 U.S.C. $\$ 7408(a)(2)(A)(1994)$. 
frequently include many individuals who possess just such special sensitivities to pollution, ${ }^{55}$ stricter application of the CAA's requirements offers EPA a powerful statutory basis for addressing environmental justice concerns. The Agency might find it necessary to promulgate more protective NAAQS if EPA were to consider more systematically the sensitivities of those members in environmental justice communities based on preexisting physical conditions or environmental stresses from other pollution sources. Such physical conditions or environmental stresses would seem to fall well within the meaning of those "variable factors" that EPA is authorized to consider "which of themselves or in combination with other[s]" may alter the effect of pollution levels on public health or welfare. ${ }^{56}$

EPA's statutory authority in this respect is also of a continuing nature. It does not end once a NAAQS is first promulgated. Pursuant to CAA Section 109(d), EPA is required to revise air quality criteria and standards at a minimum of every five years or as needed to ensure their adequacy in light of new information and changing circumstances. ${ }^{57}$ For example, the American Lung Association and the Environmental Defense Fund recently challenged EPA's refusal to issue a five-minute sulfur dioxide $\left(\mathrm{SO}_{2}\right)$ NAAQS, a standard that the organizations contended was especially necessary to address the health concerns of environmental justice communities vulnerable to short-term exposures to high levels of $\mathrm{SO}_{2} \cdot{ }^{58}$ Because EPA did not adequately explain its conclusion that such exposures did not lead to a public health problem, the U.S. Court of Appeals for the D.C. Circuit remanded back to EPA its order refusing to promulgate more stringent $\mathrm{SO}_{2}$ NAAQS. The D.C. Circuit's ruling, therefore, suggests more than that EPA possesses statutory authority to consider the special sensitivities of environmental justice communities when establishing air quality standards under the CAA. The CAA may, in this respect, provide an instance in which the federal law mandates such consideration.

Another CAA provision with potentially sweeping environmental justice permitting implications is Section 110 ,

55. See John S. Applegate, Risk Assessment, Redevelopment, and Environmental Justice: Evaluating the Brownfield Bargain, 13 J. NAT. RESOURCES \& ENVTL. L. 243, 280 (1997-1998) (discussing low-income and minority neighbors of brownfields as "extra-sensitive risk receptors" because of risk aggregation).

56. 42 U.S.C. $\$ 7408$ (1994).

57. Id. \& 7409(d)(1).

58. See American Lung Ass'n v. EPA, 134 F.3d 388 (D.C. Cir. 1998). 
which governs the submission of state implementation plans (SIPs) for the achievement of NAAGS. ${ }^{59}$ Section 110 describes the procedures for state submission and EPA approval of SIPs, including the minimum requirements necessary to secure EPA approval. Section $110(a)(2)(E)$ sets forth one of those requirements, which is that the SIP shall "provide ... necessary assurances that the State . . . will have adequate . . . authority under State . . . law to carry out such implementation plan (and is not prohibited by any provision of Federal or State law from carrying out such implementation plan or portion thereof)." ${ }^{" 60}$ To the extent that Title VI of the Civil Rights Act constitutes "any provision of Federal . . . law" within the meaning of Section $110(a)(2)(E)$, this CAA provision may provide EPA with both authority and responsibility to ensure that SIPs, including their permitting provisions, do not result in the kind of disparate environmental results Title VI condemns. ${ }^{61}$

The CAA's nonattainment provisions for areas not in compliance with NAAQS air pollutant criteria also offer several opportunities. ${ }^{62}$ An explicit objective of Subchapter D's Nonattainment Program is "to assure that any decision to permit increased air pollution in any area to which this section applies is made only after careful evaluation of all the consequences of such a decision and after adequate procedural opportunities for informed public participation in the decisionmaking process." Prior to the redesignation of any nonattainment area, there must be notice and a public hearing in the areas proposed to be redesignated. ${ }^{64}$ Prior to that hearing, "a satisfactory description and analysis of the health, environmental, economic, social, and energy effects of the proposed redesignation shall be prepared ...."65 Here, too, the statutory terms easily sweep environmental justice concerns within their broadly worded mandate. Among "all the consequences" of allowing increased

59. 42 U.S.C. $\$ 7410$ (1994).

60. Id. \& 7410(a)(2)(E).

61. EPA is apparently considering the possibility of this very linkage between the CAA and Title VI. See Letter from Mr. David P. Howekamp, Director, Air Division, USEPA Region IX, to Mr. Michael Kenny, Executive Officer, California Air Resources Board (Dec. 23, 1997) (copy on file with author) ("A complaint under Title VI of the Civil Rights Act has been fled with EPA regarding [Southern California Air Quality Management Division] Rule 1610. This complaint leads to uncertainty about whether or not the requirements of Section $110(\mathrm{a})(2)(\mathrm{E})$ are being met. Until this uncertainty has been resolved, EPA Region 9 will not take action on SCAQMD Rule 1610.").

62. See 42 U.S.C. $\$ \$ 7501-7515$ (1994).

63. Id. $\$ 7470(5)$ (emphasis added).

64. Id. \& 7407(d)(3) \& (4).

65. Id. $\$ 7474(\mathrm{~b})(1)(\mathrm{A})$ (emphasis added). 
air pollution should be the impact of such an increase on a community that is already exposed to environmental stresses from other sources or that is otherwise especially sensitive to such increases. Perhaps even more directly on point, however, is the Act's extension of the analysis prior to redesignating a nonattainment area to include consideration of the "social" effects of any such redesignation. The "social" modifier makes relevant the kind of community concern implicated by facility siting that often does not seem to fall neatly within the ambit of an environmental protection law.

Finally, the relevant provision setting forth sanctions in the event of a violation of the CAA's nonattainment provisions likewise could be more effectively enlisted to address environmental justice concerns. The sanctions provision includes a catchall clause extending to "such additional measures as the Administrator may reasonably prescribe." ${ }^{66}$ What is "reasonable" in specific circumstances could legitimately take environmental justice concerns, including priorities, into account.

Another provision of the CAA that may allow for greater incorporation of environmental justice concerns into risk aggregation is the waiver provision for innovative technological systems of continuous emission reduction applicable to the new source performance standards in Section $111 .{ }^{67}$ To determine whether an applicant for a waiver is exempt from requirements otherwise applicable to the owner or operator of a new source, the applicant must demonstrate "to the satisfaction of the Administrator that the proposed system will not cause or contribute to unreasonable risk to public health." 68 The statutory emphasis on public health and inclusion of the phrase "contribute to" should allow EPA to consider the cumulative public health impacts of a facility on the affected community.

The Act's nonattainment provisions provide further potential environmental justice opportunities. ${ }^{69}$ Section 173 describes the requirements for a nonattainment permit. ${ }^{70}$ An explicit permit requirement in the Act mandates that "an analysis of alternative sites, sizes, production processes, and environmental control techniques for such proposed source demonstrates that benefits of the proposed source significantly outweigh the environmental and social costs imposed as a result of its location, construction,

66. Id. \& 7509(d).

67. Id. $\S 7411(\mathrm{f})$.

68. Id. $\$ 7411 \mathrm{j}(1)(\mathrm{A})(\mathrm{iii})$ (emphasis added).

69. See id. $\S \S 7501-7515$.

70. See id. $\$ 7503$. 
or modification."71 The references to both "social costs" and "location" serve as strong bases for EPA's assertion of statutory authority to take environmental justice concerns into account in evaluating the "location" of a facility seeking a nonattainment permit.

Another CAA provision expressly authorizing consideration of a facility "location" can be found in Section 112(r)(7), which establishes a program addressing the prevention of accidental releases of hazardous air pollutants. Section 112(r)(7) provides:

In order to prevent accidental releases of regulated substances, the Administrator is authorized to promulgate release prevention, detection, and correction requirements which may include monitoring, record-keeping, reporting, training, vapor recovery, secondary containment, and other design, equipment, work practice, and operational requirements. Regulations promulgated under this paragraph may make distinctions between various types, classes, and kinds of facilities, devices and systems taking into consideration factors including, but not limited to, the size, location, process, process controls, quantity of substances handled, potency of substances, and response capabilities present at any stationary source. ${ }^{72}$

This authority is not directly tied to the issuance of a permit, but presumably EPA has the discretion to incorporate into its permits the regulations authorized by this provision.

Section 112 also includes two other subsections relevant to environmental justice priorities. Section 112(c)(3) and Section $112(\mathrm{k})$ both authorize EPA to consider the aggregate effects of multiple sources of hazardous air pollutants, especially those emitted in urban areas. ${ }^{73}$ Section 112 (c)(3) provides that the "Administrator shall list . . . each category or subcategory of area sources which the Administrator finds presents a threat of adverse effects to human health or the environment (by such sources individually or in the aggregate) warranting regulation under this section." The Administrator must list "sufficient categories or subcategories of area sources to ensure that area sources representing 90 percent of the area source emissions of the 30 hazardous air pollutants that present the greatest threat to public health in the largest number of urban areas are subject

71. Id. $\$ 7503(\mathrm{a})(5)$ (emphasis added).

72. Id. \& 7412(r)(7).

73. Id. $\$ 7412(\mathrm{c})(3),(\mathrm{k})$.

74. Id. § 7412(c)(3) (emphasis added). 
to regulation under this section. ${ }^{75}$ Section $112(\mathrm{k})$ further mandates that EPA create by November 15, 1995, "a comprehensive strategy to control emissions of hazardous air pollutants from area sources in urban areas." 76 The strategy must identify no fewer than thirty hazardous air pollutants presenting the greatest threat in urban areas. ${ }^{77}$ The strategy also must identify the source categories or subcategories that emit such pollutants and provide "a schedule of specific actions to substantially reduce the public health risks posed by the release of hazardous air pollutants from area sources that will be implemented by the Administrator under the authority of this or other laws ... or by the States." 78

Yet another CAA provision expressly authorizing EPA to promulgate regulations pertaining to the siting or location of polluting facilities is Section 129(a)(3), which provides for the siting of solid waste incinerators. Section 129(a)(3) provides that standards promulgated under CAA Sections 111 and 129 applicable to solid waste incineration units must "incorporate for new units siting requirements that minimize, on a site specific basis, to the maximum extent practicable, potential risks to public health or the environment."79 Such "siting requirements" could possibly extend to environmental justice matters. The reference to "site specific basis," in particular, supports the Administrator's consideration of a community's specific circumstances with the aim of minimizing potential public health risks. Such circumstances should logically include possible risk aggregation attributable to preexisting public health or environmental risks that the community already faces.

EPA's enforcement authority under the CAA likewise allows the Agency to take into account environmental justice concerns in allocating its enforcement resources. ${ }^{80}$ EPA's decision to initiate a civil or criminal enforcement action is generally a matter of agency discretion to exercise as the Administrator deems "appropriate. ${ }^{\text {" } 1}$ There is reason to believe that historically federal and state enforcement of environmental protection laws did not occur at a level commensurate with the environmental

75. Id.

76. Id. $\S 7412(\mathrm{k})(3)(\mathrm{A})$.

77. See id. $\$ 7412(k)(3)(B)(1)$.

78. Id. $\S 7412(\mathrm{k})(3)(\mathrm{c})$.

79. Id. § 7429(a)(3).

80. See id. \$ 7413 .

81. Id. $\S 7413(\mathrm{~b})$. 
risks prevalent in environmental justice communities. ${ }^{82}$ Under the CAA, EPA has discretion to reallocate its enforcement resources in a manner that more actively serves those communities with government oversight and enforcement of the statute's requirements by treating enforcement of CAA violations in environmental justice communities as especially "appropriate." 83

Even more specifically, the CAA's penalty assessment criterla would seem to allow the Administrator to consider the special need for a credible enforcement threat in those communities that have not generally benefited from enforcement in the past. ${ }^{84}$ Section 113(e)(1) provides that "[1]n determining the amount of any penalty to be assessed," the Administrator shall consider several specific factors and "such other factors as justice may require. " 85 Some of these "other factors" have been interpreted in various EPA Regions to include "litigation risks," such as evidentiary problems, ${ }^{86}$ and "inability to pay" in the case of seriously financially troubled businesses. ${ }^{87}$ The Administrator could find that environmental justice concerns coupled with the absence of past government enforcement and the lack of community resources to oversee a facility's compliance are causes for enhanced penalties assessed for violations in certain communities. The logical nexus would be the need to bolster deterrence in circumstances such as those present in many environmental justice communities where there is cause for concern that government and citizen oversight of regulated facilities' compliance with environmental laws has been relatively lacking.

In the context of permitting, the CAA provisions of greatest interest are those that may allow EPA (or a state permitting authority that has assumed permitting responsibility pursuant to CAA Section 502) ${ }^{88}$ greater discretion in using the permitting process to increase community participation and build

82. See Richard J. Lazarus, Pursuing "Environmental Justice": The Distributional Effects of Environmental Protection, 87 Nw. U. L. REV. 787 (1993); see also RoBERT D. BUllard, Dumping in DIXIE: Race, Class, AND ENVIronmental gualty (1990); Foster, supra note 18.

83. 42 U.S.C. $§ 7413(e)(1)$ (1994).

84. See id.

85. Id.

86. Environmental Protection Agency, Region 4, Clean Air Act Stationary Source Clull Penalty Policy (last visited Nov. 15, 1998) <http://www.epa.gov/region4/ air/enforce/penpol.pdf>.

87. Id.

88. 42 U.S.C. $\$ 7661 \mathrm{a}(\mathrm{d})(1994)$. 
community enforcement capacity. Section 504 would seem to confer on EPA just such authority. ${ }^{89}$ Subsection (a) provides that "[e]ach permit issued under this subchapter shall include... such other conditions as are necessary to assure compliance with applicable requirements of this chapter...."90 A major component for achieving compliance assurance under the CAA is the citizen suit provision of that statute. ${ }^{91}$ Without that provision acting as a credible enforcement threat, there is no assurance of compliance. ${ }^{92}$ Therefore, Section 504(a) may authorize EPA to impose upon those receiving CAA permits the condition that they take certain steps to enhance the affected community's ability to ensure that the permitted facility complies with applicable environmental protection laws. Such conditions could range from simply providing more ready access to the information necessary to overseeing the permitted facility's operation and compliance to working to increase the resources of citizen groups participating in environmental oversight and compliance assurance.

To that same effect, Section 504(b) authorizes EPA to prescribe "procedures and methods for determining compliance,"93 and Section 504(c) requires that each permit "set forth inspection, entry, monitoring, compliance certification, and reporting requirements to assure compliance with the permit terms and conditions." 94 There is nothing on the face of the statute to preclude either Section 504(b)'s "procedures and methods" or Section 504(c)'s "requirements to assure compliance" from extending to permit conditions that enhance the community's own capacity to oversee the permitted facility's compliance.

Finally, Section 128 of the $\mathrm{CAA}^{95}$ may provide the Administrator with the authority to ensure that state permitting boards and pollution control enforcement authorities are sensitive to environmental justice concerns. Section 128 mandates that SIPs require that "any board or body which approves permits or enforcement orders under this chapter shall have at least a majority of members who represent the public

89. Id. $\S 7661 \mathrm{c}$.

90. Id. \$7661c(a).

91. Id. \$ 7604 .

92. See supra notes 9-14 and accompanying text.

93. 42 U.S.C. $\$ 7661 \mathrm{c}(\mathrm{b})$ (1994).

94. Id. $\$ 7661 \mathrm{c}(\mathrm{c})$.

95. Id. $\S 7428$. 
interest." The "public interest" standard may allow the Administrator to require that persons concerned with environmental justice issues or representatives of environmental justice communities be included on state boards or bodies with permitting or enforcement authority.

\section{Clean Water Act}

As with the CAA, there are multiple opportunities within the Clean Water Act (CWA) ${ }^{97}$ for EPA itself to modify environmental standards to respond better to environmental justice concerns. For example, Section 302 authorizes the Administrator to promulgate restrictions supplemental to the Act's technologybased controls if, absent such additional restrictions, the discharges "would interfere with the attainment or maintenance of that water quality in a specific portion of the navigable waters which shall assure protection of public health ...."98 Although the Agency has historically been wary of invoking Section 302, the provision does provide EPA with some statutory authority beyond technology-based controls to address environmental justice concerns by relating those concerns to the protection of "public health." I9 Individual states are also required under Section 304( $l$ ) to develop individual control strategies for releases of toxic pollutants that inhibit the states' ability to attain or maintain applicable water quality standards. ${ }^{100}$

The water quality standard provisions of the CWA offer another opportunity for EPA to exercise its authority to consider and address environmental justice concerns. Under the CWA, states must establish water quality standards applicable to waters within the states' borders. ${ }^{101}$ Unlike the CAA's NAAQS, which are nationally uniform, these state water quality standards may not only vary between states, but need not be uniformly applied to all water bodies within any one state. ${ }^{102} \mathrm{~A}$ state may legitimately apply different levels of water quality protection to different water bodies depending on the specific uses (for example, recreation, transportation, or industry) the state designates for each body of water. EPA oversees a state's

96. Id. $\S 7428(\mathrm{a})(1)$.

97. Federal Water Pollution Control Act, 33 U.S.C. \&\$ 1251-1387 (1994) (Clean Water Act).

98. 33 U.S.C. § 1312(a) (1994).

99. Id.

100. Id. \& $1314(0)(1)(\mathrm{D})$.

101. Id. § 1313; see PERCIVAL, supra note 19, at 936-45.

102. See PERCIVAL, supra note 19 , at $937,938-40$. 
promulgation of water quality standards primarily to ensure that the standards are consistent with the state's "designated uses" 103 but also to ensure compliance with EPA's nondegradation policy, which guards against unwarranted degradation of existing uses of water and associated water quality. ${ }^{104}$ CWA permits must ensure compliance not only with the Act's various technologybased effluent limitations, but also with the state water quality standards. The latter aspect of the Act requires the federal (or state) agency responsible for permitting, first, to determine the total maximum daily loads (TMDLs) of pollutants consistent with the water quality standard applicable to each body of water and, second, to allocate those loads among all the sources contributing pollutants to the water body. ${ }^{105}$ Because of the practical and political obstacles in making each of these two determinations, EPA and the states have historically made little headway in their implementation until very recently. ${ }^{106}$

The water quality program is especially relevant to environmental justice because it involves EPA and the states making a series of judgments with clearly distributional consequences. For instance, EPA's nondegradation policy, which protects "existing uses" of water, should provide protection to such existing uses by environmental justice communities, including those that are economically or culturally dependent on the subsistence use of water. TMDL planning, however, is even more relevant. EPA can ensure, through its oversight of state TMDL determinations, that the resulting allocations do not unfairly burden low-income communities or communities of color.

The CWA also confers authority on the Administrator to promote environmental justice when imposing monitoring and reporting requirements on owners and operators of point sources. To assist the Administrator in developing pollution control effluent limitations or standards, or in determining whether a violation of a limitation or standard has occurred, Section 308 authorizes the Administrator to require point sources to maintain records, make reports, use monitoring

103. Id. at 939.

104. See 40 C.F.R. \$ 131.12(a)(2) (1998); PERCIVAL, supra note 19, at 938.

105. The TMDL is the maximum amount of a pollutant that all sources can contribute to a water segment without causing a violation of the water quality standard. See 33 U.S.C. $\$ 1313(d)(1)(C)$ (1994); PERCIVAL, supra note 19, at 943-45.

106. See generally Oliver A. Houck, TMDLs, Are We There Yet?: The Long Road Toward Water Quality-Based Regulation Under the Clean Water Act, 27 Envtl. L. Rep. (Envtl. L. Inst.) 10,391 (1997). 
equipment, sample effluent, and "provide such other information as he may reasonably require. ${ }^{\text {107 }}$ Section 308 further provides that the Administrator "or his authorized representative" has the right to reasonable access and inspection. ${ }^{108} \mathrm{Here}$, too, the Administrator could invoke these authorities creatively to promote environmental justice community enforcement capacity. Monitoring reports and general compliance information could be directed to community groups, obviating the need to travel to inconvenient locations. Even more provocative is the possibility that, in appropriate circumstances, the Administrator could designate a local community organization her "authorized representative" and thereby allow the organization a right of entry and inspection.

In addition to providing EPA with discretionary authority to target its resources when enforcing the CWA in a manner more responsive to the needs of environmental justice communities, the CWA also permits administrative and civil penalties to take into account environmental justice. Section 309(d) provides that civil penalties may be calculated based on several factors including "such other matters as justice may require"; Section $309(\mathrm{~g})$, regarding administrative penalties, includes identical language. ${ }^{109}$ The use of the term "justice" in this context confers on EPA considerable discretionary authority beyond that provided in those instances where the exclusive statutory touchstone is "health and the environment."110 Environmental justice's distinct concerns with disproportionality and equity easily fall within the rubric of "justice." So, too, would this language seem to allow EPA to determine that a civil penalty should be increased for facilities located in areas (such as some environmental justice communities) where enforcement has long been lacking, and therefore increased deterrence is warranted.

Section 402 of the CWA, however, is likely the most significant potential source of permit conditioning authority. ${ }^{111}$ Section 402 provides that the Administrator may issue a permit

107. 33 U.S.C. $\$ 1318(a)(A)(1994)$.

108. Id. § 1318 (a)(B).

109. Id. § 1319(d), (g).

110. See, e.g., 15 U.S.C. § 2604(f)(1) (1994) (requiring EPA to take measures that protect against "unreasonable risk of injury to health or environment" caused by manufacture, processing, distribution in commerce, use, or disposal of a chemical substance under the Toxic Substances Control Act); 42 U.S.C. \& 6924(q)(2)(B) (1994) (allowing certain record keeping and labeling exceptions under RCRA for facilities where waste is burned with such efficiency that "protection of human health and environment is assured").

111. 33 U.S.C. $\$ 1342$ (1994). 
for the discharge of any pollutant:

upon condition that such discharge will meet either (A) all applicable requirements under sections $301,302,306,307$, 308 , and 403 of this title, or (B) prior to the taking of necessary implementing actions relating to all such requirements, such conditions as the Administrator determines are necessary to carry out the provisions of this chapter. ${ }^{112}$

A broad construction of clause (B) could confer on the Administrator wide ranging authority to impose permit conditions promoting environmental justice. This clause contains, however, two limitations: (1) the authority exists only prior to the taking of certain necessary implementing actions; and (2) the conditions must carry out the provisions of the CWA. Both conditions could be met. The Administrator most certainly has not taken all implementing actions under several provisions, including, for example, Section 302 discussed above. Moreover, because the purpose of the permit conditions would be to protect public health, public water supplies, and promote compliance assurance, it should not be difficult to fashion permit conditions that both promote environmental justice concerns, including community enforcement capacity and risk aggregation, and "carry out the provisions of this chapter."

\section{Resource Conservation and Recovery Act}

Many provisions of the Resource Conservation and Recovery Act (RCRA) include broad wording that leaves EPA with substantial authority to take into account environmental justice concerns in the Agency's implementation of this Act. The touchstone for the Agency's promulgation of regulations under Sections 3002, 3003, and 3004 applicable to generators, transporters, and owners and operators of hazardous waste treatment, storage, and disposal facilities is the same: "as may be necessary to protect human health and the environment."113 One of the major lessons of environmental justice is that EPA's past failure to account for aggregation of risks and cumulative impacts has caused EPA's existing standards to fail to protect human health and the environment in certain communities.

112. Id. § 1342(a)(1) (emphasis added); see Bradley C. Bobertz, The Tools of Prevention: Opportunities for Promoting Pollution Prevention Under Federal Environmental Legislation, 12 VA. ENVTL. L.J. 1, 6-7 (1992) (discussing "such conditions as the Administrator determines are necessary to carry out the provisions of this chapter" as a "generous grant of authority").

113. 42 U.S.C. \$§ 6922(a), 6923(a), 6924(a) (1994). 
EPA's authority under RCRA to correct this problem cannot be gainsaid. The relevant statutory language specifically directs the Agency to accomplish an objective that can be achieved only by considering the actual (including aggregated) human health and environmental effects of hazardous waste management on disparately affected low-income communities or communities of color.

RCRA's Section 3004 applies to owners and operators of hazardous waste treatment, storage, and disposal facilities, and elaborates further on the kinds of standards that EPA may promulgate. ${ }^{14}$ Several standards have significant implications for environmental justice. For example, Section 3004(a) provides that EPA standards shall include requirements pertaining to:

(2) satisfactory reporting, monitoring, inspection, and compliance ... ;

(4) the location, design, and construction of such hazardous waste treatment, disposal, or storage facilities;

(5) contingency plans for effective action to minimize unanticipated damage . . . ;

(6) the maintenance of operation of such facilities and requiring such additional qualifications as to ownership... training for personnel . . . as may be necessary or desirable ... . ${ }^{115}$

EPA could fashion "reporting, monitoring, and inspection" requirements in a manner more responsive to the needs of environmental justice communities, which tend to have fewer resources available to engage in the effective oversight of a regulated facility's compliance with environmental performance standards. EPA is authorized to impose requirements relating to the "location" of treatment, storage, and disposal facilities. ${ }^{116}$ This authorization presumably permits the Agency at the very least to account for risk aggregation in the siting of such facilities. The reference to "contingency plans" should allow EPA to require contingency plans reflecting the needs of environmental justice communities that, because of their own limited resources, may require the owner and operator to invest more resources into the community to develop and implement such plans. Finally, EPA could consider the socioeconomic, 
racial, and ethnic makeup of a community in promulgating requirements regarding "qualifications as to ownership . . . [and] training for personnel."117 A major problem in the past was the lack of adequate training to bridge the gap between the community and a regulated facility located within that community. ${ }^{118}$ Special training may be needed for personnel operating facilities within these communities, possibly including the training and hiring of more individuals who are themselves residents of the affected community.

In addition, Section 3004(0)(7) may provide EPA with the authority to consider the location of hazardous waste treatment, storage, and disposal (TSD) facilities in order to address environmental justice concerns. ${ }^{119}$ Those requirements could, in turn, be enforced through RCRA's Section 3005 permitting program. $^{120}$ Section $3004(0)(7)$ provides that the revised TSD regulations shall "specify criteria for the acceptable location of new and existing treatment, storage, or disposal facilities as necessary to protect human health and the environment." ${ }^{121} \mathrm{EPA}$ could construe "acceptable" as embracing the kinds of concerns reflected in the President's Environmental Justice Executive Order. ${ }^{122}$ Those opposing such a construction of the statute would likely refer to the next sentence of the statute, which includes the phrase "areas of vulnerable hydrogeology," arguing that EPA's determination of "acceptable locations" is confined to technical issues of a particular location's geology. Because, however, the issue would not be what EPA is required to do, but the full extent to which the statute confers discretionary authority to EPA, a broader construction of "acceptable location" might well prevail. EPA could further maintain that nothing suggests Congress intended the explicit reference to "hydrogeology" to be exclusive of the kinds of factors that EPA could consider relevant in deciding whether a particular location is "acceptable."

EPA also possesses the authority under RCRA to target its enforcement resources in a manner more responsive to the needs

117. See, e.g., id. $\$ 6924(a)(6)$ (discussing considerations for owning and operating a facility).

118. See generally Conference, supra note 6, at 700 (addressing "concerns that people have about facility siting" and providing for "training of community representatives on how they can better participate in the process of clean-up around facilities that are in proximity to their communities").

119. 42 U.S.C. \$ 6924(0)(7) (1994).

120. Id. § 1325.

121. Id. $\$ 1324(0)(7)$ (emphasis added).

122. See Executive Order, supra note 15. 
of environmental justice communities. ${ }^{123}$ RCRA differs from the CAA and CWA because it does not include an express provision that the penalty for a violation may be based on "justice." 124 Instead the Administrator is instructed to account for the "seriousness of the violation" as one factor in calculating the appropriate penalty in a compliance order. ${ }^{125}$ In many circumstances, environmental justice concerns could relate to the "seriousness" of a particular violation, such as when the associated risks are particularly aggregated, disproportionate or inequitable, or when the risks are imposed on an especially sensitive community.

EPA's inspection authority under RCRA is likewise amenable to implementation in a manner more responsive to environmental justice. EPA has inspection authority, but so too does a "duly designated representative" of the Agency. ${ }^{126}$ Records, reports, or other information obtained by EPA pursuant to its inspection authority are required to be made publicly available. ${ }^{127}$ EPA could strive to ensure that such information is meaningfully available to those residing in communities who might not otherwise have ready access to formally "available" documents, but only for those with the necessary resources to gain physical access and the expertise to understand them. ${ }^{128}$ EPA is also authorized to "distinguish between classes and categories of facilities commensurate with the risks posed by each class or category" to ensure thorough and adequate inspection of regulated facilities. ${ }^{129}$ Arguably, classes or categories of facilities significantly warranting special attention are those located in environmental justice communities.

With regard to permit conditions, EPA may have substantial authority to consider environmental justice in deciding to grant,

123. See 42 U.S.C. \$ 6928 (1994) for federal enforcement regulations under RCRA.

124. See, e.g., id. § 7413(e)(1) (CAA civil penalty assessment); 33 U.S.C. § 1319(d) (1994) (CWA civil penalty determination).

125. 42 U.S.C. \$ 6928(a)(3) (1994) (describing civil penalty provisions for noncompliance under RCRA).

126. Id. § 6927(a).

127. Id. \& 6927(b).

128. Many EPA documents are available only to those who travel to EPA regional offices where there are rooms where public records are made available. Even then, not all documents are readily comprehensible to a layperson, especially if English is not the reader's first language. $C f$. El Pueblo Para el Aire y Agua Limpio v. County of Kings, [1999] 22 Envtl. L. Rep. (Envtl. L. Inst.) 20,357, 20,358 (Cal. Super. Ct. Dec. 30,1991 ) (reversing siting decision of toxic waste incinerator on grounds that public zoning process was publicized only in English to primarily Spanish speaking community concerns).

129. 42 U.S.C. \& 6927(e)(1) (1994). 
conditionally grant, or deny a permit by considering the possibility that a particular community is subject to disparate environmental risks. ${ }^{130}$ As described by EPA's own Environmental Appeals Board ${ }^{131}$ in In re Chemical Waste Management, Inc., ${ }^{132}$ Section 3005(c)(3) provides that "[e]ach permit issued under this section shall contain such terms and conditions as the Administrator (or the State) determines necessary to protect human health and the environment." ${ }^{133}$ As in Sections 3002, 3003, and 3004, this language in the permitting provision allows the Agency to "tak[e] a more refined look at its health and environmental impacts assessment in light of allegations that operation of the facility would have a disproportionately adverse effect on the health or environment of low-income or minority populations." ${ }^{34}$ Such a close, "more refined look" could, in turn, justify permit conditions or denials based on the adverse impacts disparately affecting a community that might otherwise be "mask[ed]" if the regulator undertook only an "analysis of a broad cross-section of the community." 135

Permit conditions could, however, be even more far reaching. Protecting human health and the environment turns on compliance assurances; accordingly, permit conditions might extend to communities needing to increase their enforcement capacity. As previously discussed, ${ }^{136}$ such enforcement capacity is essential to accomplish RCRA objectives, especially in lowincome communities and communities of color that, because of a history of lacking enforcement capacity, have been the repeat victims of environmental noncompliance. ${ }^{137}$

Finally, RCRA Section 4002 governing the federal guidelines for state solid waste management plans is worthy of special mention. Among the considerations relevant to promulgating

130. See, e.g., id. \$ 6925(g)(1), (j)(7)(A).

131. The Environmental Appeals Board is the administrative appeals tribunal of EPA. See Changes to Regulations to Reflect the Role of the New Environmental Appeals Board in Agency Adjudications, 57 Fed. Reg. 5320 (1992); see also William A. Tilleman, Environmental Appeal Boards: A Comparative Look at the United States, Canada, and England, 21 CoLUM. J. ENVTL. L. 1, 13 (1996). EPA's Environmental Appeals Board and its environmental justice precedent are more fully discussed later in this Article. See infra Part IV.

132. In re Chemical Waste Management, Inc., 1995 WL 395962 (E.P.A. June 29, 1995). This opinion is more fully discussed infra at text accompanying notes 216237.

133. Id. at *5 (discussing RCRA, 42 U.S.C. \$ 6925(c)(3) (1994)).

134. Id. at *6.

135. Id.

136. See supra Part I.B.

137. See supra Parts I.A, I.B. 
those guidelines are "the political, economic, organizational, financial, and management problems affecting comprehensive solid waste management." ${ }^{138}$ While many disagreements exist regarding the meaning and portent of environmental injustice claims, little dispute exists that environmental justice presents a major "political" problem affecting solid waste management. ${ }^{139}$ For the same reason, Section 4002 plainly authorizes EPA to include in its guidelines for state solid waste management plans recommendations for how a state might best establish a model program for addressing environmental justice concerns related to solid waste management.

\section{E. Safe Drinking Water Act}

The Safe Drinking Water Act (SDWA) ${ }^{140}$ includes many of the same kinds of interpretative opportunities already mentioned in the context of the CAA, CWA, and RCRA. The EPA Administrator retains the usual significant discretion to target enforcement based on environmental justice factors and, as with the CAA and CWA, civil penalties are assessed based on several factors including "such other matters as justice may require."141 Environmental justice concerns can be readily injected into enforcement if "justice" in the civil penalty provision is interpreted as including concerns such as equity, risk aggregation, and harm disproportionality.

In some respects, though, the SDWA may be especially amenable to incorporating environmental justice concerns because of the statute's broad wording. For example, the Act directs the Administrator to promulgate national primary drinking water regulations pursuant to several factors, one of which is a catchall provision: "other factors relevant to protection of health." ${ }^{142}$ The kinds of risk aggregation and cumulative impacts disparately affecting environmental justice communities would seem to be such a relevant factor. In addition, to establish the list of contaminant level goals, the Administrator forms an advisory working group that must include members

138. 42 U.S.C. \$ 6942(c)(9) (1994).

139. See generally William C. Scott, Environmental Justice: A New Era of Community Empowerment, Political Activism, and Civil Rights Litigation, 7 ENVTL. ClaIMS J. 5 (1994) (discussing Executive Order's recognition of national trends to concentrate high impact solid waste disposal facilities in low-income or minority communities).

140. 42 U.S.C. $\$ \$ 300$ fo $300 j-26$ (1994).

141. Id. \$ $300 \mathrm{~h}-2(\mathrm{c})(4)(\mathrm{B})(\mathrm{vi})$.

142. Id. \& $300 \mathrm{~g}-1(\mathrm{~b})(7)(\mathrm{C})(\mathrm{i})$. 
from several specified offices (for example, Office of Drinking Water, Pesticides, Toxic Substances) "and any others the Administrator deems appropriate." ${ }^{43}$ In light of Executive Order $12,898,{ }^{144}$ the Office of Environmental Justice could now easily be considered another "appropriate" office for this advisory working group. That office should, by its mission-oriented nature, provide the advisory working group with the environmental justice perspective historically absent from EPA's policy deliberations.

Finally, although the Act permits a state with primary enforcement to grant variances from national primary drinking water regulations to public water systems, ${ }^{145}$ the statute further provides that any such variance "shall be conditioned on such monitoring and other requirements as the Administrator may prescribe." 146 Here, too, the Administrator could strive to fashion conditions that reflect the noncompliance risks faced especially by many environmental justice communities. ${ }^{147}$ Such conditions could be, as earlier discussed in the context of other statutes, ${ }^{148}$ either less or more far reaching in their scope. The former could take the form of requirements that community organizations be provided information and allowed public participation and compliance oversight opportunities. The latter could extend to specific requirements for resource assistance to community representatives as needed to allow them to take meaningful advantage of those opportunities.

\section{F. Toxic Substances Control Act}

The Toxic Substances Control Act (TSCA) ${ }^{149}$ is one of the few environmental laws to include an explicit environmental justice program, albeit of a quite limited scope. The Act contains provisions dealing with technical and grant assistance to the states for radon programs expressly targeting "homes of lowincome persons" for such assistance. ${ }^{150}$

143. Id. § 300g-1(b)(3)(B).

144. 3 C.F.R. 859 (1995).

145. 42 U.S.C. \$ 300g-4(a)(1)(B) (1994).

146. Id.

147. See Gauna, supra note 11 , at $32-37$ (discussing incentives for facilities to pollute in low-income and minority communities where penalties for noncompliance are significantly lower).

148. See supra Parts II.A to II.D and text accompanying notes.

149. 15 U.S.C. $\$ \S 2601-2692$ (1994).

150. Id. $\$ \S 2665(a)(6), 2666(1)(2)$. Although the assistance provisions of the other laws do not include such a mandate, neither do they expressly preclude such a preference, and based on the Executive Order on Environmental Justice, EPA plainly 
Like the other environmental laws, TSCA's substantive standards are susceptible to an agency interpretation that addresses environmental justice concerns. Particularly relevant is TSCA's instructing EPA to consider, among other factors, "cumulative or synergistic effects" in determining the regulatory border between reasonable and "unreasonable risk[s] to health or the environment."151 Such effects are precisely those that environmental justice advocates contend have been overlooked too often in considering the risks imposed by toxic substances on low-income communities and communities of color.

Finally, TSCA is significant because Congress explicitly instructed the Administrator to "carry out" the law by considering the "environmental, economic and social impact of any action the Administrator takes." ${ }^{\text {152 }}$ Hence, wholly apart from the Executive Order on Environmental Justice, ${ }^{153}$ EPA possesses wide ranging authority in implementing TSCA to address environmental justice concerns in fashioning and enforcing the Act's requirements.

\section{G. Federal Insecticide, Fungicide, and Rodenticide Act}

The Federal Insecticide, Fungicide, and Rodenticide Act (FIFRA) $^{154}$ confers substantial authority on the EPA Administrator to address environmental justice concerns. EPA's principal responsibility in administering FIFRA is its registration of pesticides to guard against "unreasonable adverse effects on the environment." 155 Environmental justice advocates are interested in FIFRA's administration for many reasons, one of which is the substantial threat to the health of farmworkers posed by the unreasonably dangerous use of pesticides. ${ }^{156}$ FIFRA provides EPA with significant authority to eliminate these unreasonable risks through tactics as varied as use restrictions, disposal restrictions, labeling requirements, registration denials, and conditional registrations. EPA's authority is broadly worded

has the authority to provide it.

151. Id. \& 2603(b)(2)(A).

152. Id. $\$ 2601$ (c) (emphasis added).

153. Executive Order, supra note 15.

154. 7 U.S.C. $\S \S 136-136 y$ (1994).

155. Id. \$ $136 \mathrm{a}(\mathrm{a})$.

156. See John Megara, The Rose Industry Exception for Early Entry Into Pesticide Treated Greenhouses: Romance in Regulation, 25 B.C. ENVTL. AFF. L. Rev. 941, 945-46 (1998); Ivette Perfecto \& Baldemar Velasquez, Farmworkers: Among the Least Protected, EPA J., Mar./Apr. 1992, at 13. 
and turns on the "unreasonable adverse effects"157 touchstone, thereby leaving the Agency with significant discretionary authority to take into account wide ranging concerns when implementing FIFRA. Environmental justice concerns with risk accumulation, cumulative effects, and worker notice all fall easily within the core of the Agency's regulatory authority under FIFRA. ${ }^{158}$

III

ENVIRONMENTAL PERMITTING GUIDELINES INCORPORATING ENVIRONMENTAL JUSTICE CONCERNS: EXPERIENCES FROM EPA REGIONAL OFFICES

To comply with Executive Order 12,898, several regional EPA offices currently incorporate environmental justice considerations into their permitting protocols. ${ }^{159}$ Although the guidelines by which these environmental justice considerations are taken into account "do not create any rights, duties or obligations with respect to any third parties," they outline processes by which the regional staff can determine whether a case should be considered a potential environmental justice case, and if so, what course of action should be taken. All of these processes are advisory, not mandatory, and most focus on enhancing public participation rather than imposing specific additional permit requirements. Nevertheless, the existence of such guidelines suggests that at least some regional EPA offices consider it within their discretion to take into account environmental justice considerations when exercising their permitting responsibilities.

The regional cases discussed in this Article are not intended to be exhaustive of all related permitting activities currently considered by EPA regional offices. The particular environmental justice permitting programs examined by this Article are those with available public documentation or those collected from a telephone survey conducted in the Fall of 1998 of all regional offices. As such, the permitting programs discussed in this Article are intended to be illustrative only. Moreover, some of these activities may well have been prompted by the

157. 7 U.S.C. \& 136a(a) (1994).

158. See generally id.

159. Each EPA Regional Office is responsible within selected states for executing EPA's programs. These, in turn, have programs for specific areas or issues in environmental protection, such as air protection or hazardous site cleanup. The environmental justice permitting protocols are informal or formal procedural guidelines established by the programs for incorporating environmental justice concerns in the permitting process. 
dissemination of an earlier version of this Article, which took the form of an EPA advisory counsel memorandum. If these regional activity examples seem somewhat sparse and unevenly distributed among regional offices, that is simply an accurate reflection of the originality of this Article's proposals and those actions already being undertaken by some of the regions, perhaps in response.

\section{A. Experiences from EPA Region $V$}

\section{Resource Conservation and Recovery Permitting}

EPA Region V has responded to environmental justice concerns in the RCRA permitting process by increasing public response procedures. ${ }^{160}$ In addition, the Region V RCRA office has created a permits workgroup that has drafted a "permit writer's checklist" used as a screening device for sites with environmental justice implications and included in the administrative docket. The Region V RCRA program office has addressed two sites that raise environmental justice concerns: the Environmental Enterprises Incorporated (EEI) facility (a RCRA treatment, storage, and disposal permit renewal) located in Cincinnati, Ohio, and the Adams Center Landfill (a landfill expansion permit) located in Fort Wayne, Indiana. ${ }^{161}$ The Cincinnati community raised environmental justice concerns in regard to the EEI facility's air emissions. ${ }^{162}$ The Region used a risk analysis methodology for fugitive air emissions to address human health and environmental effects, and pursued enhanced enforcement and public outreach for the EEI facility. ${ }^{163}$ In Fort Wayne, local religious, civil rights, and citizen groups raised environmental justice concerns in regard to the expansion of the Adams Center Landfill. ${ }^{164}$ The Region performed a demographic analysis and conducted additional public outreach for the Adams Center Landfill but after several public meetings found that further risk analysis and assessment were not necessary to address environmental justice concerns. ${ }^{165}$

160. See U.S. Envtl. Protection Agency, Waste Programs Environmental Justice Program-Specific Issues: Resource Conservation and Recovery Act (visited Nov. 17. 1998) <http://www.epa.gov/swersops/ej/pdf/rcra.pdf >

161. See id.

162. See id.

163. See id.

164. See id.

165. See id. 


\section{Lead Permitting}

As of June 1998, Region V provides interim guidelines in the context of EPA lead permitting decisions in Section VI of its Interim Guidelines for Identifying and Addressing a Potential Environmental Justice Case. ${ }^{166}$ The Guidelines encourage state agencies to consider environmental justice during the permitting process by first determining whether the demographics of the impacted population are disproportionately low-income and/or minority. ${ }^{167}$ If such an analysis suggests environmental justice concerns, then the state agencies are encouraged to examine whether the cumulative impact of the source in question and the existing sources are likely to create a disproportionate impact. ${ }^{168}$ Nevertheless, even when increased public participation and strengthened permit conditions are suggested as a result of the state agency finding disproportionate environmental effects, the Interim Guidelines state that "[t]he appropriate response to a finding of disproportionate effect will rarely be permit denial; and this should be clearly explained to the public." 169

The Region V Interim Guidelines then step through procedural suggestions for screening a community's demographic potential for raising environmental justice concerns, ${ }^{170}$ and, in cases where potential environmental justice issues are identified, considering disproportionate impacts from existing sources. ${ }^{171}$ In encouraging procedures that facilitate

166. U.S. ENVTL. PROTECTION AGENCY REgION 5, REVISED REgION 5 INTERIM GUIDELINES FOR IDENTIFYING AND ADDRESSING A POTENTIAL ENVIRONMENTAL JUSTICE CASE (1998) (on file with author). This document may also be found at Environmental Justice Regional Team, U.S. Envtl. Protection Agency. Region 5 Interim Guidelines for Identifying and Addressing a Potential Environmental Justice Case (visited July 7 , 1999) <http://www.epa.gov/envjustice/ejguidelines.html>.

167. Id. section VI.

168. See id.

169. Id.

170. Id. section VI, pt. I. The screening guidelines portion of the Region V Interim Guidelines cautions that an impacted community may extend beyond the community in the location of the source and encourages an initial determination of the area of impact based on knowledge of the type and effect of a particular source. The guidelines next advise state agencies to make the results of a demographic analysis publicly available once they are obtained and to contact the division tribal coordinator if an impacted American Indian population is identified. Finally, the guidelines refer state agencies to Section VII of the Interim Guidelines for an "Environmental Justice and Community Involvement Protocol."

171. Id. section VI, pt. II. Three stages of review are outlined in this section of the Interim Guidelines: (A) how to "determine whether there are any other current or pending permits in this area administered by the same Division," (B) how to "determine whether there are any other current or pending permits in this area administered by other Divisions," and finally, (C) how to "consider other 
community self-identification of environmental justice issues, the Interim Guidelines state that "adequate community participation is an [environmental justice] issue whether or not the permitting team identifies a disproportionate effect."172 Thus, the Region V Interim Guidelines emphasize the value of procedural, as well as result-oriented, protection for environmental justice communities.

When there are disproportionate effects, the Interim Guidelines suggest two broad areas of response: (1) enhancing public participation, and (2) exercising authority to set permit conditions. To enhance the public participation process, the Guidelines recommend that the Region "exercise its discretion to assure early and ongoing opportunities for public involvement in the permitting process" and "provide public participation opportunities beyond the required minimum." 173 The Guidelines provide specific guidance through its Environmental Justice and Community Involvement Protocol. ${ }^{174}$

The Interim Guidelines accept that enough authority exists in current statutes and regulations to allow EPA discretion to write permits that take into account disproportionate effects. To do so, EPA suggests possible actions of adding supplementary monitoring requirements, extra steps to reduce risk, more stringent standard operating procedures, or additional requirements for emergency preparedness.

\section{Air and Radiation Division Environmental Justice} Implementation Plan

Along with increasing the availability of citizen participation opportunities, the Region V EPA Air and Radiation Division, in its Environmental Justice Implementation Plan, ${ }^{175}$ recognizes the

environmental stresses which may contribute to disproportionate effects in the community." Id.

172. Id. section VI, pt. III. In an attempt to cushion state agencies from procedural delays, the Interim Guidelines also warn that "self-identification as [environmental justice] by a non-[environmental justice] community should not be allowed to unduly delay EPA's permitting decision." Id.

173. Id. section VI, pt. IV.

174. The "Environmental Justice and Community Involvement Protocol" section of the Interim Guidelines presents four major steps: (1) tdentifying stakeholders, (2) preparing community involvement plans or communications strategies, (3) hosting public meetings and availability sessions, and (4) following-up after public meetings. Id. section VII.

175. U.S. Envtl. Protection Agency, Region 5, Air and Radiation Division Environmental Justice Implementation Plan FY98 (visited July 7, 1999) <http://www.epa.gov/reg5oair/ej/98plan.htm> [hereinafter Implementation Plan]. 
need exemplified in adjudicated environmental justice matters ${ }^{176}$ to provide not only technical assistance but also legal assistance to the environmental justice communities to ensure meaningful participation. The Region's Plan suggests that the Regional Office will "assist EPA headquarters (HQ) in the review of existing Federal permitting regulations and determine appropriate avenues to address [environmental justice] issues within the existing framework." ${ }^{177}$ This assistance addresses the need to provide a level playing field for low-income and minority communities, not only during the public participation process but also within the political and legal processes. Where explicit latitude is not given, the Region will nevertheless address environmental loading, cumulative effects, and environmental justice communities' concerns about the permitting process.

B. Experiences from Region IX Air Division Environmental Justice Strategy

The Air Division of Region IX has been developing an environmental justice strategy to comply with Executive Order 12,898 and to "maximize environmental justice through the practical and attainable prevention, control and removal of criteria pollutants and toxic air emissions from designated affected communities including tribal nations in Region IX."178 The Strategy expands upon the communities addressed in Title VI by explicitly focusing federal attention on low-income communities as well as tribal nations, ethnic groups, minority groups, age groups, and gender groups.

Formal methodological recommendations are not given in the Strategy; rather, its emphasis is on providing criteria for assessing an environmental justice problem and goals that the permit office can flexibly meet. ${ }^{179}$ The Strategy notes that it derives its authority ${ }^{180}$ from EPA regulations to implement Title VI, ${ }^{181}$ the Equal Protection Clause of the Fourteenth

176. See, e.g., In re Genesee Power Station, L.P., 1993 WL 484880 (E.P.A. Sept. 8, 1993) (Genesee I), modified by In re Genesee Power Station, L.P., Order on Motion for Clarification, 1993 WL 473846 (E.P.A. Oct. 22, 1993) (Genesee In).

177. Implementation Plan, supra note 175.

178. SAM AGPAWA \& ROY FORD, EPA REGION IX AIR DIVISION ENVIRONMENTAL JUSTICE STRATEGY 3 (July 27, 1998) (document in development) (on file with author) [hereinafter STRATEGY].

179. Id. at 6.

180. Id.

181. 40 C.F.R. $\$ \S 7.10-7.135$ (1998). 
Amendment, ${ }^{182}$ as well as the discretionary authority that the Regional Air Division possesses under the National Environmental Policy Act, ${ }^{183}$ the Clean Air Act, ${ }^{184}$ the Uniform Relocation Act, ${ }^{185}$ NAFTA, ${ }^{186}$ and the La Paz Agreement. ${ }^{187}$

With respect to permitting, the Region $I X$ Strategy encourages the Permits Office to provide up front support for permit applicants to promote community involvement and consult with division and regional environmental justice coordinators to assess the possible environmental justice concerns of proposed major permitting actions in order to assess the extent of an individual public participation program. In addition, the Strategy encourages the Permits Office to encourage state and local districts to involve affected communities in the permitting program and to incorporate systematic consideration of environmental justice concerns into their own permitting programs. ${ }^{188}$ The Strategy also provides that "the Permits Office will encourage the districts to include [environmental justice] elements in the rule making process to the extent permitted by law." 189

IV

EPA ENVIRONMENTAL APPEALS BOARD DECISIONS REGARDING THE RELATIONSHIP OF ENVIRONMENTAL JUSTICE TO EPA PERMITTING AUTHORITY

The evolving perspective of the Environmental Appeals Board ${ }^{190}$ on EPA's authority to base permits on environmental justice grounds can be seen in a series of decisions beginning in September $1993^{191}$ and continuing to the present. ${ }^{192}$ Although

182. U.S. ConST. amend. XIV, § 1 .

183. National Environmental Policy Act of 1969, 42 U.S.C. $\$ \$ 4321-4370(e)$ (1994).

184. Clean Air Act Amendments of 1990, 42 U.S.C. \$§ 7401-7671q (1994).

185. Uniform Relocation Assistance and Real Property Acquisition Policies Act of 1970, 42 U.S.C. \$§ 4601-4655 (1994) (amended 1987).

186. North American Free Trade Agreement, Dec. 17, 1992, Can.-Mex.-U.S., 32 I.L.M. 289.

187. Agreement on Cooperation for the Protection and Improvement of the Environment in the Border Area, Aug. 4, 1983, U.S.-Mex., T.I.A.S. No. 10,827.

188. STRATEGY, supra note 178 , at 6 .

189. Id.

190. The Environmental Appeals Board is an administrative "court" within EPA, established in 1992, to handle the Agency's administrative appeals process. Changes to Regulations to Reflect the Role of the New Environmental Appeals Board in Agency Adjudications, 57 Fed. Reg. at 5320: see also Tilleman, supra note 131, at 13-14 (describing form and function of Environmental Appeals Board).

191. See Genesee I. $1993 \mathrm{WL} 484880$. This decision was modified by Genesee II, 1993 WL 473846.

192. See In re Knauf Fiber Glass, GmbH, 1999 WL 64235 (E.P.A. Feb. 4, 1999). 
the Executive Order on Environmental Justice ${ }^{193}$ expressly did not enlarge any agency's permitting power, the Order has had a marked effect on the Board's interpretation of the scope of authority available to permitting agencies. Prior to the Order, the Board rejected an environmental justice community's claim that environmental justice concerns should be considered in an air quality permitting process. The Board held instead that permitting agencies lacked environmental justice authority because they were limited to considering whether a facility would meet federal air quality requirements. ${ }^{194}$

After the Order was issued, the Board seemed to accord increasingly more acceptance to the contention that permitting agencies were able to condition permits on environmental justice grounds. ${ }^{195}$ Although none of these decisions required agencies to interject environmental justice considerations into their permitting processes, the opinions focused less on whether complainants were able to claim that agencies failed to consider environmental justice concerns and more on whether those agencies adequately considered environmental justice concerns. The net effect of the Order may have been to draw attention to existing areas of authority that the Board had previously overlooked so that agencies had the means to actually comply with the Order.

In later Board decisions, the notion that agencies were able, and indeed encouraged, to consider environmental justice concerns became routine. ${ }^{196}$ Lack of permitting authority was no longer a per se defense to complaints of disparate impacts arising from permitting. The Board began to accept even informal agency guidelines as appropriate bases for environmental justice determinations. The litigated issues now revolve around factual questions of whether agencies had appropriately found that projects would have no significant disparate impact on low-income or minority communities.

193. Executive Order, supra note 15.

194. See Genesee I, 1993 WL 484880; Genesee II, 1993 WL 473846.

195. See generally in re Envotech, L.P., 1996 WL 66307 (E.P.A. Feb. 15, 1996); In re Puerto Rico Electric Power Auth., 1995 WL 794466 (E.P.A. Dec. 11, 1995); In re Chemical Waste Management, Inc., 1995 WL 395962 (E.P.A. June 29, 1995).

196. See, e.g., In re Knauf Fiber Glass, GmbH, 1999 WL 64235 (E.P.A. Feb. 4, 1999); In re Environmental Disposal Systems, Inc., 1998 WL 723912 (E.P.A. Oct. 14, 1998); In re Ash Grove Cement Co., 1997 WL 732000 (E.P.A. Nov. 14, 1997); In re EcoElectrica; L.P., 1997 WL 160751 (E.P.A. Apr. 8, 1997). 
A. Lack of Environmental Justice Authority

\section{Genesee I}

The Environmental Appeals Board's institutional reluctance to find agency environmental justice conditioning authority is evident in the Board's final environmental ruling in In re Genesee Power Station, L.P. (Genesee 1), ${ }^{197}$ which occurred before President Clinton signed the Environmental Justice Executive Order. ${ }^{198}$ In Genesee I, a local environmental justice community organization (the Society of Afro-American People) challenged a state agency's decision to grant a prevention of significant deterioration (PSD) permit under Section 165 of the CAA. ${ }^{199}$ The citizen group contended, among other things, that the decision to locate the facility in a predominantly African American community reflected environmental racism. ${ }^{200}$

In its initial ruling, the Board concluded that the state agency lacked authority under the provisions of the federal CAA to consider community opposition. ${ }^{201}$ The Board noted that as a result, the state agency's failure to consider such opposition was entirely appropriate and consequently could not be deemed evidence of a racially discriminatory intent. The Board noted that the state agency's inquiry was properly confined under the federal statute to the question of whether the facility would meet federal air quality requirements. ${ }^{202}$ Community opposition, the Board reasoned, would normally be a matter for consideration by a local zoning board. ${ }^{203}$

The Board further found that even if the state agency had authority under some state law to consider community opposition thus authorizing the Board to review the state's compliance with that state law, the state agency's actions were not discriminatory. ${ }^{204}$ The Board rejected the community group's claim of disparate impact, which was based on the state agency's denial of a permit for an incinerator opposed by white residents in Marquette County, Michigan. ${ }^{205}$ The Board found that there

197. Genesee I, 1993 WL 484880.

198. Executive Order, supra note 15.

199. 42 U.S.C. § 7475 (1994).

200. See Genesee I, 1993 WL 484880 , at *4.

201. See id.

202. See id. at *6.

203. See id. at *7.

204. See id. at *6.

205. See id. at $* 5$. 
were "legitimate, nondiscriminatory reasons" for denying the permit in Marquette County, but not in the instant case. ${ }^{206}$ In the Marquette County permit denial, the local zoning approval had been denied, the incinerator's proximity to a wetland would have violated the federal Wild and Scenic Rivers Act, and the facility would not have complied with state law. ${ }^{207}$ While noting that the plaintiffs failed to prove the state agency's discriminatory intent under the Equal Protection Clause, the Board also explicitly declined to reach that constitutional issue. $^{208}$ The Board further held that the residents' health and safety were not threatened, as "emissions allowed under the PSD permit will not be permitted to exceed, and in certain instances will be far below, applicable air quality standards adopted to protect human health and welfare."209

\section{Genesee II}

EPA's Office of General Counsel (OGC) responded to the Board's ruling in Genesee $I$ by filing a Motion for Clarification (Genesee $I$ ), ${ }^{210}$ in which the OGC requested that the Board revise its reasoning but not the results. Specifically, the OGC challenged the Board's rationale that a state agency (acting as a PSD permitting authority under federal delegation) lacks authority to consider community opposition to the proposed facility location so long as the air quality impacts of the facility meet federal requirements. Although the Board responded in a hostile fashion to the OGC's motion- "The Board does not view its function as that of making its legal views consistent with those of program and Regional offices .... [T]he Board was created in part to ensure that the controversies pending before it are decided fairly and impartially"211 — the Board ultimately agreed to excise the portions of the initial opinion considered objectionable by the OGC. ${ }^{212}$ Those portions included the Board's statements that the permitting agency lacked authority under federal clean air legislation to consider community opposition. The Board reasoned that excision was appropriate because these were issues of national importance that deserved

206. Id.

207. See id. at *6.

208. See id.

209. Id.

210. Genesee II, 1993 WL 473846.

211. Id. at*1.

212. See id. 
greater attention. ${ }^{213}$

\section{Lessons Learned from the Genesee Decisions}

The two Genesee administrative rulings illustrate the pitfalls of having environmental justice addressed in a case by case fashion. Both the state agency and EPA- in the form of the Appeals Board-followed natural impulses to deny the legitimacy of a new claim, namely, the promotion of environmental justice concerns. Without any form of external guidance such as an executive order, the agencies read statutory authorities narrowly rather than expansively, presumably to insulate the agency's decisionmaking from second-guessing by outsiders.

Juxtaposing the two decisions, however, illustrates the potential for positive reforms, even prior to the existence of external executive pressures, for EPA to take the initiative outside the adjudicatory process to read its authorities more expansively. Because the OGC in this case took the initiative, the Board modified its reasoning so as not to preclude the Agency from embracing a more proactive approach to environmental justice in subsequent matters. The challenge the Agency then faced, and continues to face, is to fill gaps in the law regarding the relevancy of environmental justice concerns in permitting decisions before those gaps are filled in a manner unsympathetic to environmental justice by agency employees and state environmental agencies interpreting relevant authorities in adjudicatory settings. Once the government has "dug in" a legal position, it is far harder to effectuate needed reforms.

Finally, one other lesson to take away from the Genesee decisions is the significance of community enforcement capacity. The Board concluded that "legitimate nondiscriminatory reasons" existed for why the state denied the permit to locate the facility in a white community but granted the permit to locate the facility in the African American community. Perhaps so, but perhaps similar violations of state law might have been developed in a legal challenge had the African American community possessed the legal resources and political power necessary to do so. It requires substantial resources, for example, to make a showing that a particular site is ill-suited for the location of a facility presenting certain kinds of environmental risks. Detailed

213. See id. at $* 2$. 
geologic and atmospheric analyses of the relevant site may be necessary. So, too, may epidemiological and toxicological expertise be required. The Board's assumption that different results in prior state permit proceedings reflect actual differences between sites is understandable but may nonetheless be quite mistaken. What it may in fact reflect is differences in resources possessed by communities, which is why even what appear to be entirely "legitimate nondiscriminatory reasons" may be the product of yet a different kind of inequity.

EPA's recognition of such legal and political inequities and their implications may be necessary to fully address any environmental justice concerns. Indeed, in their absence, environmental injustices may, perversely, self-perpetuate. The Agency could, as may have occurred in Genesee II, readily conclude that no inequity is presented in a case before it by unwittingly relying on facts that are themselves the product of inequity. Hence, past injustices can beget future injustices.

\section{B. Increasing Willingness to Find Discretionary Authority}

During the period immediately following the President's signature of Environmental Justice Executive Order 12,898, ${ }^{214}$ the Environmental Appeals Board became increasingly more sympathetic toward finding the existence of discretionary authority to condition a permit on environmental justice grounds. To some extent, even the challenged agencies themselves had performed discriminatory impact analyses to determine whether environmental justice conditions should be imposed. ${ }^{215}$ The shift toward a willingness to find authority is evident in the opinions of three substantial Board decisions.

\section{In re Chemical Waste Management, Inc.}

In In re Chemical Waste Management, Inc. ${ }^{216}$ local citizens challenged on environmental justice grounds EPA Region V's decision to grant a permit to a landfill pursuant to RCRA Section 3005. ${ }^{217}$ The Region held an informational meeting with concerned citizens and industry representatives to discuss,

214. Executive Order, supra note 15.

215. See, e.g., In re Envotech, L.P., 1996 WL 66307, at *11 (E.P.A. Feb. 15, 1996); In re Puerto Rico Electric Power Auth., 1995 WL 794466, at *3 (E.P.A. Dec. 11, 1995); In re Chemical Waste Management, Inc., $1995 \mathrm{WL} 395962$, at $* 8$ (E.P.A. June 29 , 1995).

216. 1995 WL 395962 (E.P.A. June 29, 1995).

217. 42 U.S.C. $\S 6925$ (1994). 
among other items, environmental justice issues. ${ }^{218}$ The Region also prepared a demographic study based on a one-mile radius around the facility. ${ }^{219}$

The citizens' challenge included several arguments based explicitly on environmental justice concerns. ${ }^{220}$ The citizens claimed that the Region had acted in a clearly erroneous fashion and had abused its discretion in seeking to implement Executive Order 12,898 in the absence of the Agency's promulgation of a national environmental justice strategy. They also contended that the demographic study was clearly erroneous because of its restricted one-mile radius scope and because the Region had ignored evidence regarding the impacts of the permitted facility and the racial and socioeconomic composition of the affected area. $^{221}$

The Board rejected both contentions. It concluded that Executive Order 12,898 "does not purport to, and does not have the effect of, changing the substantive requirements for issuance of a permit under RCRA and its implementing regulations. ${ }^{\text {222 }}$ The Board further concluded that "if a permit applicant meets the requirements of RCRA and its implementing regulations, the Agency must issue the permit, regardless of the racial or socioeconomic composition of the surrounding community and regardless of the economic effect of the facility on the surrounding community. ${ }^{223}$

The Board then sought to temper what otherwise appeared to be a blanket rejection of any statutory authority to consider environmental justice concerns in the permitting context. The Board held that "when the Region has a basis to believe that operation of the facility may have a disproportionate impact on a minority or low-income segment of the affected community, the Region should, as a matter of policy, exercise its discretion to assure early and ongoing opportunities for public involvement in the permitting process. ${ }^{224}$ The Board, therefore, supported enhancing avenues for public participation when environmental justice concerns are raised.

The more significant part of the opinion, however, is that portion in which the Board goes beyond procedural requirements

218. See Chemical Waste Management, $1995 \mathrm{WL} 395962$, at *3.

219. See id. at *4.

220. See id. at *3.

221. See id.

222. Id. at *4.

223. Id. at *5 (emphasis added).

224. Id. 
to consider the possible substantive significance to environmental justice under the omnibus clause in RCRA Section 3005(c)(3): "[e]ach permit issued under this section shall contain such terms and conditions as the Administrator (or the State) determines necessary to protect human health and the environment." 225 The Board agreed that this clause requires the Agency to condition, and if necessary, to deny a permit "if the operation of a facility would have an adverse impact on the health or environment of the surrounding community" as necessary to prevent such impacts. ${ }^{226}$ The Board concluded that EPA had the authority under RCRA to take "a more refined look at its health and environmental impacts assessment" in response to environmental justice claims. ${ }^{227}$ The Board specifically acknowledged that an assessment looking only at "a broad analysis might mask the effects of the facility on a disparately affected minority or low-income segment of the community." 228 Accordingly, the Board held that:

when a commenter submits at least a superficially plausible claim that operation of the facility will have a disproportionate impact on a minority or low-income segment of the affected community, the Region should, as a matter of policy, exercise its discretion under Section 3005(c)(3) to include within its health and environmental impacts assessment an analysis focusing particularly on the minority or low-income community whose health or environment is alleged to be threatened by the facility. ${ }^{229}$

Finally, the Board stressed that the omnibus clause in Section 3005(c)(3) could not be used as a statutory basis for injecting into the analysis factors other than "ensuring the protection of the health or environment or low-income populations. The Region would not have discretion to redress impacts unrelated or only tenuously related to human health and the environment, such as disproportionate impacts on the economic well-being of a minority or low-income community. ${ }^{230}$

Notwithstanding the stark terms of the Board's threshold suggestion that "the racial or socio-economic composition of the surrounding community" is irrelevant to the permitting authority under RCRA, the Board's opinion leaves substantial room for

225. 42 U.S.C. \$ 6925(c)(3) (1994).

226. Chemical Waste Management, 1995 WL 395962, at *6.

227. Id.

228. Id.

229. Id.

230. Id. (footnote omitted). 
EPA to exercise its authority to promote environmental justice when exercising its permitting authority under RCRA. The opinion allows the Agency to engage in the kind of risk aggregation analysis upon which environmental justice claims are frequently grounded. This includes a closer examination of both the cumulative impacts of various risk producing facilities affecting an environmental justice community as well as the possibility that certain subpopulations may be differentially susceptible to harm from environmental pollutants. The Board also suggested a potentially low threshold trigger for the preparation of such analysis: "a superficially plausible claim [of] ... disproportionate impact on a minority or low-income segment of the affected community."231

Perhaps even more significantly, the Board appeared to have ruled that permit conditions or denials do not depend on the showing of a violation of some pre-established environmental standard. The Board opinion provided that EPA has authority to condition a permit whenever "the operation of a facility would have an adverse impact on the health or environment of the surrounding community" as necessary to prevent such impacts. ${ }^{232}$ The Board did not make clear what it meant by "an adverse impact" ${ }^{233}$ and how it intended to square this aspect of its opinion with its initial admonishment that "if a permit applicant meets the requirements of RCRA and its implementing regulations, the Agency must issue the permit."234 Presumably, though, they are reconciled by the Administrator being given discretion in Section 3005(c)(3)'s omnibus provision to determine what constitutes an adverse impact warranting a condition or a denial. ${ }^{235}$ The Board, therefore, did not deny to the Administrator permitting authority under RCRA to consider the socioeconomic or racial composition of a community so long as the Administrator does so only as a reason to take a closer look at the human health and environmental effects of the facility seeking a permit. ${ }^{236}$ The final permit condition or denial must rest on those effects and not simply on the socioeconomic or racial composition of the community. ${ }^{237}$

231. Id.

232. Id.

233. Id.

234. Id. at *5 (emphasis added).

235. See id. at *6.

236. See id.

237. See id. 


\section{In re Puerto Rico Electric Power Authority}

In In re Puerto Rico Electric Power Authority, ${ }^{238}$ a citizen group in Puerto Rico sought review of EPA Region II's issuance of a PSD permit to the Puerto Rico Electric Power Authority (PREPA). The group claimed, among other things, that PREPA and Puerto Rico should have prepared an epidemiological study of the area surrounding the proposed facility and that their failure to do so violated Executive Order 12,898 and the United States Constitution. ${ }^{239}$ The Board rejected the claim, relying on Region II's explanation that it had fully responded to environmental justice issues raised during the comment period, including the preparation of a demographic analysis of the affected area. The Region concluded that the facility "would cause no disproportionate adverse health impacts to lower-income populations." ${ }^{240}$ Finally, the Board likewise rejected the citizen group's contentions that the Region had relied on flawed meteorological data and had failed to consider adequately PREPA's "history of violations."

The precedential significance of this decision is fairly limited because the citizen group's petition for review appears to have been too cursory to be persuasive. ${ }^{242}$ The matter is nonetheless significant because it underscores both the limited resources available to most community-based environmental justice organizations and the importance of EPA's adoption of a more proactive view of its affirmative ability to promote environmental justice in the permitting context. It is no great surprise that when, as in this case, an EPA region declines to actively pursue the environmental justice concerns of an affected community, the Board will almost always affirm that ruling. ${ }^{243}$ Unless the local community group has managed to obtain substantial legal expertise and resources, the group is unlikely to be able to articulate their concerns in a manner likely to prompt the Appeals Board to second-guess the Region. As the Board emphasized, it will not grant a petition for review "unless the decision is based on either a clearly erroneous finding of fact or conclusion of law, or involves an important matter of policy or

238. 1995 WL 794466 (E.P.A. Dec. 11, 1995).

239. See id.

240. Id. at $* 3$ (citation omitted).

241. Id.

242. See id. at *2 (describing petition as a "two page letter" "lacking in specificity").

243. See, e.g., id.; Genesee I, 1993 WL 484880; Genesee II, 1993 WL 473846. 
exercise of discretion that warrants review."244

For that same reason, however, effective promotion of environmental justice will depend on a region's willingness to respond proactively to a local community group's concerns by exercising its discretion to take the initiative to become closely engaged with those in the community. When, as in this case, the issue becomes what the Agency is required to do, rather than simply authorized to do, environmental justice advocates will most often lose. Moreover, only with the Region's provision of resources will those advocates be able to make the weighty factual and legal presentations necessary to persuade decisionmakers of the possible merit of their arguments. ${ }^{245}$

\section{In re Envotech, L.P.}

In In re Envotech, L.P., ${ }^{246}$ local residents and nearby municipalities challenged EPA Region V's decision to grant two underground injection control (UIC) permits under the Safe Drinking Water Act. ${ }^{247}$ The permits authorized Envotech to drill, construct, test, and operate two hazardous waste injection wells in Washtenaw County, Michigan. ${ }^{248}$ The local opposition raised many objections, including Envotech's poor history of environmental compliance, the unsafe and unproven nature of underground injection, the absence of necessary state and local governmental approvals, flawed geological assessments, errors in characterizations of the hazardous wastes to be received by the facility, and failure to provide required waste minimization certification. ${ }^{249}$ The residents also raised distinct environmental justice claims alleging that the permits should be denied because the area already hosted many undesirable land uses. ${ }^{250}$

The Board rejected all of the claims raised by the local groups except for the claim that a waste minimization certification was required. ${ }^{251}$ The Board specifically denied the contention of a community organization opposed to the facility,

244. Puerto Rico Electric Power Auth, 1995 WL 794466, at 2 (citing 40 C.F.R. \$ 124.19(a)).

245. See id. at *2 (rejecting petition as "so lacking in specificity as to why the Region's decision is erroneous that petitioner has provided the Board with no basis for review").

246. 1996 WL 66307 (E.P.A. Feb. 15, 1996).

247. See id.

248. See id. at *2.

249. See id at $* 7-11$.

250. See id at $* 11$.

251. See id. at $* 26$. 
Michigan Citizens Against Toxic Substances, that the existence of local opposition alone provides a basis for a UIC permit denial. ${ }^{252}$ The Board reasoned that "local opposition alone is simply not a factor that the Region may consider in its permit decision" and that "[m]ore fundamental issues, such as siting of the wells, are a matter of state or local jurisdiction rather than a legitimate inquiry for EPA." 253

The Board also rejected opposition to the permit based on the past environmental compliance or lack thereof of companies affiliated with Envotech. ${ }^{254}$ The Board concluded that such a concern "simply does not present a link to a condition of the UIC permits at issue here sufficient to invoke the Board's authority to review the permit decision." 255 The Board similarly found no basis for relief in any of the environmental justice claims, which focused on the fact that the area surrounding the facility was already host to numerous burdensome land uses.

The Board, however, used the matter as another opportunity to state its views on the significance of environmental justice in the permitting context. Citing its earlier ruling in Chemical Waste Management, the Board stated that, as with RCRA permitting under Section 3005, "if a UIC permit applicant meets the requirements of the SDWA and UIC regulations, the 'Agency must issue the permit, regardless of the racial or socio-economic composition of the surrounding community and regardless of the economic effect of the facility on the surrounding community."'256 But, as in Chemical Waste Management, the Board went on to identify "two areas in the UIC permitting scheme in which the Region has the necessary discretion to implement the mandates of the Executive Order. ${ }^{257}$

The "two areas" described by the Board as existing within the Safe Drinking Water Act UIC program ${ }^{258}$ are virtually the same as those described by the Board in Chemical Waste Management as existing within RCRA. ${ }^{259}$ The first area is the right to public participation, allowing the Region to "exercise its discretion to assure early and ongoing opportunities for public involvement in

252. See id. at *8.

253. Id.

254. See id. at *9.

255. Id.

256. Id. at*13 (citing Chemical Waste Management, 1995 WL 395962 , at *9).

257. Id at *14.

258. 40 C.F.R. § 144.52(a)(9) (1998).

259. 42 U.S.C. $\S 6925$ (c)(3) (1994). 
the permitting process." ${ }^{260}$ The second area is the discretionary authority the Board derived from the "regulatory "omnibus authority' contained in 40 C.F.R. $\$ 144.52(a)(9)$," which authorizes "permit conditions 'necessary to prevent the migration of fluids into underground sources of drinking water."'261 The Board reasoned that "there is nothing in the omnibus authority that prevents a Region from performing a disparate impact analysis when there is an allegation that the drinking water of minority or low-income communities may be particularly threatened by a proposed underground injection well." ${ }^{262}$ Finally, the Board concluded that in order to implement Executive Order 12,898 , the Region should exercise its discretionary authority to undertake such an analysis "when a commenter submits at least a superficially plausible claim that a proposed underground injection well will disproportionately impact the drinking water of a minority or low-income segment of the community in which the well is located." 263 This creates a low threshold to initiate a disparate impact analysis and shifts the burden to the Region to respond by examining the environmental justice concerns raised by the proposed injection well.

In this case, the Board concluded that the Region took adequate steps. ${ }^{264}$ The Board took note of the two days of informal hearings convened by the Region to allow surrounding communities to voice their concerns and the demographic analysis performed for the area surrounding the site. ${ }^{265}$ The Board upheld the Region's decision to base that analysis on a two-mile area, rejecting community opponent arguments that the subject area was too small. ${ }^{266}$

The Appeals Board's ruling is favorable to environmental justice advocates to the extent that it demonstrates the Board's willingness to find that the Agency can ground discretionary authority to promote environmental justice in the Agency's regulations. Therefore, presumably the Board does not need to rely on statutory language in the first instance. In Chemical Waste Management, the omnibus authority was contained in statutory language. ${ }^{267}$ Second, the omnibus language upon

260. Envotech, $1996 \mathrm{WL} 66307$, at *14.

261. Id. (footnotes omitted).

262. Id.

263. Id.

264. See id. at *15.

265. See id.

266. See id. at *14.

267. 1995 WL 395962 , at *9 (citing 40 C.F.R. pt. 124 and RCRA, 42 U.S.C. § 
which the Board relied on in Envotech was less obviously expansive than that construed in Chemical Waste Management. The Board's willingness to find such broad-based authority in the regulatory language "necessary to prevent migration of fluids" increases the possibility that similar omnibus authority can be found in other environmental statutes and regulations. ${ }^{268}$ As the Board explained in a footnote, the Board had already indicated that "necessary" could "arguably extend to imposition of more-stringent financial responsibility requirements than are generally prescribed for UIC permittees." ${ }^{69}$ If so, "necessary" might likewise extend to more stringent monitoring and reporting requirements, or even enhancement of community enforcement capacity, for those facilities located where there is reason to believe that absent such a condition, oversight necessary for compliance assurance will be lacking.

The more sobering assessment of the Board's opinion in Envotech is its reiteration that EPA's exercise of expansive permit authority to promote environmental justice will most likely occur only if the Agency takes the initiative. ${ }^{270}$ As in Envotech and Chemical Waste Management, neither the Board nor a reviewing court is very likely to order EPA to take such action either to condition or deny a permit. The Board's decision not to do so here is entirely consistent with its repeated characterization of EPA's authority as "discretionary" and the narrow scope of the Board's review of a Region's permitting determination. ${ }^{271}$ Hence, after Chemical Waste Management, Puerto Rico Electric Power Authority, and Envotech, the challenge EPA faced was to persuade the regional offices and delegated state permitting authorities to seize and exploit the discretionary authority that the Board had made clear that the regional offices and state authorities possessed to fulfill the mandate of Executive Order 12,898 .

\section{Recognition of Authority}

In more recent years, the Environmental Appeals Board has been more willing to explicitly recognize EPA's ability, and to some extent duty, to address environmental justice concerns

6925(c)(3) (1994)).

268. See Envotech, 1996 WL 66307, at *14.

269. Id. at *14 n.25.

270. See id. at *14 (noting that such "exercise of discretion" is a "matter of policy" in implementing the Executive Order).

271. See id. 
during the permitting process through the application of Executive Order 12,898. Although almost all of the challenges on environmental justice grounds were eventually rejected, the Board recognized the validity of such challenges generally. The issues of contention have instead shifted from the availability of permitting authority to the validity of an agency's determination that a project would have no disparate impacts, and therefore, that the agency's permitting authority need not be exercised.

\section{In re EcoElectrica, L.P.}

In In re EcoElectrica, L.P., ${ }^{272}$ an environmental organization sought review of a PSD permit granted to a cogeneration plant in Penuelas, Puerto Rico. The petitioner was concerned that the plant's air quality analysis inadequately addressed the disproportionate impact the permitting decision would have had on the nearby low-income communities. ${ }^{273}$

In response, the Region provided the mapping and census data, as well as the maximum emission impact data, that it had used to determine that the proposed facility was not located in a low-income area and that the maximum emission impacts would not occur in areas with average incomes lower than the Commonwealth of Puerto Rico average. ${ }^{274}$ The Region also emphasized that any maximum emission impacts were "insignificant" and "well below NAAQS," and therefore, would have "insignificant impacts on the surrounding communities." 275 The Region also noted that it had taken other steps specifically encouraged by the Executive Order, ${ }^{276}$ including publishing notices in Spanish language newspapers as well as English, and conducting the public hearing primarily in Spanish. Because the Board found no clear error in the Region's impact analysis, it declined to review the permit decision on environmental justice grounds.

The Board's decision to deny review seemed to be shaped partly on the vagueness of the petitioner's environmental justice challenge, which stated: "[t]he exemption of this industry from additional modeling is an example of environmental injustice." 277 The Board noted the absence of any specific basis given by the

272. 1997 WL 160751 (E.P.A. Apr. 8, 1997).

273. See id. at *9-10.

274. See id.

275. Id. at *9 (quoting the Responsiveness Summary at 5).

276. Executive Order, supra note 15, \& 5-5.

277. EcoElectrica, 1997 WL 160751, at *9 (quoting Committee's Petition at 4). 
petitioner for the contention that additional modeling should be required to address environmental justice. ${ }^{278}$ Conceivably, if the petitioner had provided reasons suggesting the necessity for further air quality impact analysis, the Board might have examined the Region's response with greater scrutiny.

Furthermore, that the Board in EcoElectrica addressed the petitioner's environmental justice challenge is cause for optimism. Relying on Chemical Waste Management ${ }^{279}$ and Envotech, ${ }^{280}$ the Board stated that it had historically encouraged EPA regional offices to "examine any 'superficially plausible' claim that a minority or low-income population may be disproportionately affected by a particular facility." ${ }^{281}$ Although the Board eventually concluded that further air quality studies would not demonstrate the type of environmental justice impacts addressed by the Executive Order, the vagueness of the petitioner's challenge was not cause, in and of itself, to reject the challenge. ${ }^{282}$ This aspect of the Board's decision may be heartening to environmental justice communities that do not have the legal resources to develop well-articulated environmental justice challenges.

Finally, the Board addressed the issue of formal guidance in a significant footnote. ${ }^{283}$ Based on its prior determinations in Chemical Waste Management ${ }^{284}$ and Envotech, ${ }^{285}$ the Board solidified its determination that absence of formal guidance or detailed written guidance "does not prevent the Agency from addressing environmental justice issues." ${ }^{286}$ The related issue of how the informal environmental justice guidances developed by various regional agencies fit into their permitting authority is addressed in both In re Ash Grove Cement $\mathrm{Co}^{287}$ and In re Environmental Disposal Systems, Inc. ${ }^{288}$

\section{In re Ash Grove Cement Co.}

A permit was challenged both for being too stringent and too

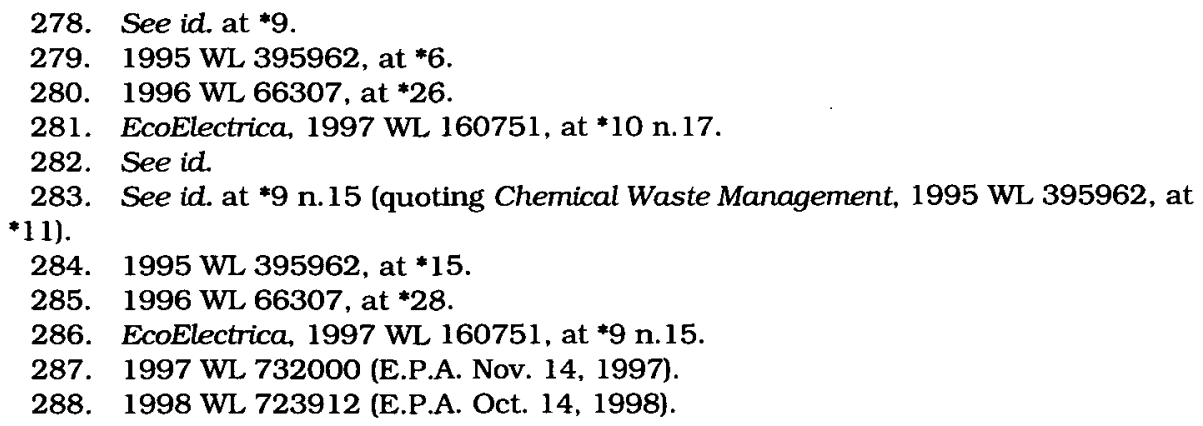


weak in In re Ash Grove Cement Co., ${ }^{289}$ in which a Chanute, Kansas, cement company challenged the conditions imposed on its RCRA permit, and competing cement companies claimed that oversights in the risk assessment process would lead to environmental justice problems. ${ }^{290}$ Cement kilns are governed under RCRA by a rule for boilers and industrial furnaces (BIF rule) that establishes emissions standards and other permit conditions based on direct exposure risk assessments of the health effects of kiln-emission inhalation. ${ }^{291}$ In the Ash Grove Cement permit process, the Region conducted not only the direct exposure risk assessment established by the BIF rule, but also the indirect effect of non-inhalation emission exposures. ${ }^{292}$ These indirect exposure risk assessments were used by the Region to justify permit conditions not mandated by the BIF rule. ${ }^{293}$

Unlike the previous Board cases involving environmental justice issues, the Region's decision to go beyond statutorilymandated concerns was based in part on an informal guidance policy, the EPA Strategy for Hazardous Waste Minimization and Combustion, ${ }^{294}$ a published strategy addressing the use of combustion to treat hazardous wastes. ${ }^{295}$ The Combustion Strategy adopted a "general policy that risk assessments, which include indirect exposure pathways, should be performed prior to final permit determinations for all hazardous waste combustion facilities." 296 The cement company challenged the Region's reliance on this guidance document, arguing that such motivation for the indirect risk assessment was improper, and therefore, the permitting conditions deriving from this assessment was also improper. ${ }^{297}$

The Board firmly rejected this challenge, stating that as long as the Region performed an individualized analysis for a

289. $1997 \mathrm{WL} 732000$, at *4-5.

290. See id.

291. See Burning of Hazardous Waste in Boilers and Industrial Furnaces, 56 Fed. Reg. 7134, 7171 (1991) (codified at 40 C.F.R. pts. 260, 261, 264-66, 270, 271).

292. See Ash Grove Cement, 1997 WL 732000, at *6.

293. See id.

294. U.S. ENVTL. PROTECTION AgENCY, Strategy FOR Hazardous Waste MINIMIZATION AND COMBUSTION (1994) [hereinafter COMBUSTION STRATEGY].

295. The Region actually claimed that it did not rely on the Combustion Strategy, but that its actions were merely consistent with the Combustion Strategy. The Appeals Board rejected this, stating that it is "clear that the Combustion Strategy was an important factor in the Region's decision to conduct risk assessment." Ash Grove Cement, 1997 WL 732000 , at*10.

296. COMBUSTION STRATEGY, supra note 294, at 23.

297. See Ash Grove Cement, 1997 WL 732000, at *9. 
particular permit, it may draw upon guidance documents in writing the permit. ${ }^{298}$ The Board found that the Region did indeed identify site-specific factors supporting the application of indirect exposure risk assessment because it was not able to obtain information relating to the direct effects of the emissions on the people of the Chanute area. ${ }^{299}$ In a strongly-worded opinion, the Board went on to state that:

[t]o hold that a Region must abstain from a particular type of inquiry simply because a procedure is not mandated by rule would attack the core of the permitting process. The Board's standard for application of policy and guidance in the permitting process preserves the necessary flexibility for the permitting agency while ensuring that the views of the permittee and others are carefully and adequately addressed. ${ }^{300}$

This assurance should provide encouragement to regional offices interested in developing their own environmental justice guidelines.

The Board then went on to address the permit challenges brought on by the competing cement companies. Along with criticisms of the Region's risk assessment methodologies, these petitioners argued that the Region violated Executive Order 12,898 by not using risk assessment to evaluate risks to the Native American populations in northern Oklahoma. ${ }^{301}$ The Board rejected this challenge, noting that "[n]either the Executive Order nor EPA's strategy specifically requires that quantitative risk assessment ... be used to identify the potential for disproportionate impacts on minority populations." ${ }^{302}$ Because the Region found the only "substantial" impacts of the cement kiln to be limited to a five-mile radius around the plant, and because very low percentages of minorities live within that fivemile radius, the Board held that it was reasonable not to perform a quantitative risk estimate of the impact of the plant on the Native American community. ${ }^{303}$ The Board suggested that to show a violation of the Executive Order, a party would need to demonstrate "how an additional analysis might disclose the kind of disproportionate impact that the environmental justice

298. See id. at *10 (relying on In re Environmental Waste Control, Inc., 1994 EPA App. LEXIS 20, at *23-24 (E.P.A. May 13, 1994)).

299. See id. at *11.

300. Id.

301. See id. at *18.

302. Id.

303. See id. 
Executive Order seeks to address." "304

It is important to note that one of the parties challenging the permit on environmental justice grounds was a competitor of the company receiving the permit. ${ }^{305}$ Although the Board did not directly base its decision on this fact, it did take notice of the challenging party's nature on several occasions, at one point stating that "certain aspects of the appeals clearly emanate from the competitive interests of the incineration and cement industries at the local and national levels." 306 Whether the Board would have decided the challenge in the same manner had it been issued from an environmental justice community itself is not clear. Perhaps in such a case the environmental justice arguments would have been or at least seemed more compelling.

\section{In re Environmental Disposal Systems, Inc.}

A very similar situation was addressed in another permit challenge, In re Environmental Disposal Systems, Inc. ${ }^{307}$ Here, Michigan State Representative Raymond E. Basham challenged two UIC permits issued to Environmental Disposal Systems authorizing construction and operation of two Class I injection wells for liquid hazardous waste disposal. ${ }^{308}$ In addition to challenging monitoring and survey requirements, Basham alleged: (1) that the environmental justice determination was flawed because the demographic analysis used a two-mile rather than four-mile radius surrounding the proposed injection wells; and (2) that under the Region's environmental justice guidelines, the consideration of aggregate impacts was inadequate. ${ }^{309}$

The Region's demographic analysis was performed pursuant to recommendations for regional guidelines, the draft Region 5 Interim Guidelines for Identifying and Addressing a Potential Environmental Justice Case. ${ }^{310}$ Using the two-mile radius demographic analysis, the Region's environmental justice review determined that the permit application did not qualify as an environmental justice case; the minority population and the lowincome population within that area were both less than the average state minority and low-income populations. ${ }^{311}$

304. Id. (citing EcoElectrica, 1997 WL 160751, at*18 n.17).

305. See id. at $* 2$.

306. Id.

307. 1998 WL 723912 (E.P.A. Oct. 14, 1998).

308. See id. at *10.

309. See id. at $* 16-17$.

310. INTERIM GUIDELINES, supra note 166.

311. See Environmental Disposal Systems, 1998 WL 723912, at*17-18. 
Significantly, nowhere in its opinion did the Board question the authority of the Region to perform such an environmental justice determination, nor did the Board question the authority of the Region to use regional interim guidelines to address environmental justice permitting concerns. ${ }^{312}$ The Appeals Board gave much deference to the Region's determination of the proper scope for its demographic study because this was a technical determination and properly within the domain of regional expertise. $^{313}$

The aggregate impact challenge rested on the premise that the Region improperly ignored the aggregate impact of the injection wells in conjunction with the existing Detroit Metropolitan airport, airport-related trucking traffic, tank farms, asphalt plant, and major interstate highways. ${ }^{314}$ The Region's response was that aggregate impacts had already been addressed in the environmental justice review, and that the review had concluded that there would be no significant impact on minority communities. ${ }^{315}$ Because the petitioner did not state why such a response was erroneous or warranted review, the Appeals Board found that this response effectively disposed of the petitioner's challenge. ${ }^{316}$

\section{In re Knauf Fiber Glass, GmbH}

The Region's duty to provide an adequate record of its environmental justice analysis, at least once that Region has developed its own environmental justice guidelines, was established in a recently decided permit challenge. In In re Knauf Fiber Glass, $\mathrm{GmbH},{ }^{317}$ petitioners challenged a PSD permit authorizing the construction of a new fiberglass manufacturing plant in the City of Shasta Lake, California. After providing statistics on the average income levels for Shasta County, the petitioners alleged that environmentai justice issues were not considered in accordance with the Executive Order. ${ }^{318}$ In response, the local Air Quality Management District (AQMD) in charge of implementing the federal PSD program asserted that the Region took the initial responsibility for making the

312. See id. at*16-18.

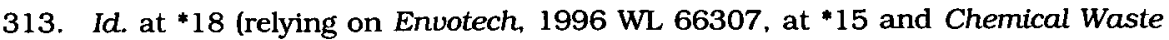
Management, 1995 WL 395962 , at *9).

314. See id.

315. See id. at*18-19.

316. See id. at *19.

317. 1999 WL 64235 (E.P.A. Feb. 4, 1999).

318. See id. at *68. 
environmental justice determination and found no violation of the guidelines. ${ }^{319}$ However, no details were available in the administrative record regarding the Region's environmental justice determination. ${ }^{320}$ A memorandum documenting a consultation between AQMD and the Region, which was added after the final permit decision, only stated that "[i]t was [the Region employee's] conclusion after reviewing the project location and surrounding demographics that it was unlikely that an Environmental Justice issue applied." ${ }^{321}$

The Board found this denial of environmental justice violations to be "cursory" and on this basis remanded the environmental justice issue, stating: "[i]f an environmental justice issue is unlikely in the context of this proposed project, we need to know the basis for that conclusion." ${ }^{322}$ The Board ordered the AQMD to provide the Region's environmental justice determination for that remand process. ${ }^{323}$ Furthermore, it ordered that this determination be made available for public comment. ${ }^{324}$

\section{In re AES Puerto Rico, L.P.}

Finally, the Environmental Appeals Board's most recent environmental justice ruling in In re AES Puerto Rico, L.P. expressly endorses EPA's discretionary authority to include permit conditions designed to address environmental justice concerns raised by the affected community. ${ }^{325}$ At issue in AES Puerto Rico was the validity of Region II's issuance of a Clean Air Act PSD permit for the construction of a 454 megawatt coal-fired power plant in Puerto Rico. ${ }^{326}$ The Board ultimately denied the various environmental justice objections made to the permit's issuance ${ }^{327}$ just as it had rejected similar claims raised in most of the other cases previously discussed. ${ }^{328}$ But here, too, the Appeals Board's rationale for its rejection bodes well for future efforts to integrate environmental justice into EPA's permit

319. See id at $* 69$.

320. See id.

321. Id. (citing Memorandum from R. Michael Kussow to Knauf Fiberglass File (June 3, 1998)).

322. Id. at *70.

323. See id.

324. See id.

325. 1999 WL 345288 (E.P.A. May 27, 1999).

326. Id. at *2-3.

327. Id. at *1-2.

328. See supra text accompanying notes 197-324. 
authority.

The gravamen of the community's objection to the PSD permit's issuance based on environmental justice was the petitioners' allegation that the low-income character of the affected community imposed on the Region greater responsibility to protect the community. ${ }^{329}$ In particular, the petitioners contended that more stringent environmental standards should have been applied and that both additional monitoring and modeling, as well as more opportunities for public participation, were necessary. ${ }^{330}$ The Appeals Board did not dispute either the legal significance of environmental justice concerns or EPA's authority to address such concerns in its permitting determinations. Instead, the Appeals Board expressly found that it is "within the Region's discretion to require" in a permit "additional conditions" that address a community's environmental justice concerns. ${ }^{331}$ The Board also undertook a detailed analysis and discussion of the array of permit conditions, enhanced public participation opportunities, and other steps the Region had undertaken in response to community environmental justice concerns. ${ }^{332}$ Such findings of discretionary authority and its proper exercise underscore how far both EPA and its Appeals Board have come since the Appeals Board's first environmental justice ruling in In re Genesee Power Station, L.P., in $1993 .^{333}$

A clear pattern emerges from the past ten years of Appeals Board rulings. The Board is no longer reflexively skeptical of the merits of environmental justice claims and has begun to consider the claims more carefully. Now, when the Board rejects environmental justice claims, it centers its rejections less on deference to regional office discretion and more on factual challenges within the scope of the environmental justice determinations already made by the regional office permitting

329. $1999 \mathrm{WL} 345288$, at *18-19.

330. See id.

331. Id. at*19.

332. The Appeals Board reviewed the "environmental justice analysis" performed by the Region, the steps the Region took "to require that many elements of the air quality analyses performed during the permit process be reconfirmed after the permit is issued," the additional monitoring requirements included by the Region as permit conditions, the supplemental information distributed by the Region to the community in response to community public health concerns, and the "expanded public comment opportunities" undertaken by the Region, including "steps to ensure that comments could be received in either English or Spanish." Id. at *19-20.

333. See supra text accompany notes 197-209. 
authorities. $^{334}$ When it has determined that available facts are inadequate, the Board has remanded the issue for further documentation and public comment. ${ }^{335}$ In all of these decisions, the Board recognized regional office authority to rely on informal environmental justice guidelines. Therefore, expected challenges to citizen groups wanting to appeal permitting decisions on environmental justice grounds will revolve more around rallying the necessary expertise to identify factual areas of contention within regional office environmental justice determinations. Such a challenge will likely prove difficult because courts have long given deference to agencies' technical determinations. The expected challenge to EPA will be to develop guidelines in which these environmental justice concerns can be adequately addressed and in which reasoned individualized determinations exist to provide factual responses to reply to any environmental justice disputes that may arise.

\section{CONCLUSION}

Existing federal laws provide environmental permitting agencies with substantial authority to address environmental justice concerns in their permitting decisions. Some laws include language that directly implicate the kinds of fairness and public health concerns raised by environmental justice. Others simply include broadly worded provisions that provide the permitting agency with considerable discretion to take the needs of environmental justice communities into account. The agency may be able to do so by denying permits, reducing the amount of permitted environmental risk, and by imposing conditions designed to enhance community participation, guard against risk aggregation, and redress unfairness presented by the disproportionate imposition of risk.

Both the Environmental Appeals Board and EPA regional offices have developed the extent of agencies' authority to condition permits on environmental justice considerations through their opinions and regional office guidelines. Although the Executive Order on Environmental Justice does not expressly expand agency authority to condition permits on environmental justice grounds, the recognized scope of this authority certainly seems larger today than before the Executive Order was issued. By accepting only factual defenses that an agency had

334. See, e.g., Environmental Disposal Systems, 1998 WL 723912, at *17-18; Ash Grove Cement Co., 1997 WL 732000, at *11; EcoElectrica, 1997 WL 160751, at *9-10.

335. See, e.g., Knauf Fiber Glass, GmbH, 1999 WL 64235, at *69. 
adequately considered disparate impact concerns, the Board provides incentives to agencies to perform environmental justice assessments prior to the issuance of permits. In that respect, much progress has been made to incorporate environmental justice concerns into environmental permitting processes. It is also likely, moreover, that EPA's new Interim Guidance for Investigating Title VI Administrative Complaints Challenging Permits will further draw agency attention to these issues and promote the further discovery of as-of-yet unrecognized areas of agency permitting authority to promote environmental justice. ${ }^{336}$ 